\title{
Cartilage Extracellular Matrix Integrity and OA
}

\author{
Chathuraka T. Jayasuriya and Qian Chen \\ Alpert Medical School of Brown Universit, Rhode Island Hospital \\ United States of America
}

\section{Introduction}

Articular cartilage tissue is mostly composed of extracellular matrix (ECM) in which a sparse population of cells (chondrocytes) reside. These cells produce both anabolic and catabolic factors that perpetuate a homeostatic process of ECM breakdown and repair termed cartilage turnover. This balance between tissue anabolism and catabolism is characteristic of normal articular cartilage. However, during osteoarthritis (OA), this process is disrupted due to disregulation of chondrocyte function. Although articular cartilage is anatomically classified as a single tissue type, it is divided into four zones defined by their physiological position relative to the joint surface. Likewise, the populations of chondrocytes housed within these zones and their respective ECMs often differ from one another in both appearance and organization. The calcified zone lies directly on top of the subchondral bone, which the cartilage tissue shields from physical forces. This zone contains a very small population of chondrocytes that are slowly being replaced by bone forming cells (osteoblasts) continuously throughout life. When compared to other cartilage zones, the calcified zone ECM is highly mineralized and contains the sparsest chondrocyte population. Osteoblasts from the neighboring subchondral bone secrete bone morphogenic factor (BMPs), and other factors such as stromal cell derived factor 1 (SDF-1) which promote chondrocyte hypertrophy and mineralization. The deep zone cartilage layer lies directly above the calcified zone and contains small vertical aggregates of chondrocytes embedded within a uniquely organized ECM which histologically resemble columnar structures. The middle zone is by far the largest layer containing round bodied chondrocytes and a well hydrated and robust collagen ECM network. Chondrocyte content increases gradually from the subchondral bone towards the articular surface that is in direct contact with the joint synovium. The superficial zone (A.K.A. tangential zone) makes up the articular surface and therefore contains the largest number of chondrocytes of all four zones. OA can affect just one or all four of these cartilage zones depending on the severity and pathological stage of the disease. Given its anatomical position, the superficial zone is often the first cartilage tissue zone to be exposed to injury or wear-and-tear due to excessive joint loading. Therefore this zone often appears to be the initial point of OA pathogenesis. During early stage OA, a sustained injury to the articular surface initially induces a mild but chronic inflammatory response (Martel-Pelletier et al., 2008) that slowly manifests into the disruption of cartilage homeostasis due to disredulation of chondrocyte function (Goldring \& Marcu, 2009). As the disease persists, continued homeostatic imbalances eventually cause the release of excessive amounts of catabolic enzymes that break down the ECM resulting in 
lesion formation within the articular cartilage tissue. Similarly, the disregulated release of anabolic factors such as BMPs and $\mathrm{IHH}$ by chondrocytes can result in chondrocyte hypertrophy and eventually calcification of the cartilage ECM. Such changes often lead to osteophyte (bone spur) formation on the otherwise smooth articular surface making normal movement painful and destructive to the connective tissue demonstrating the importance of ECM microenvironment to cartilage tissue health.

\section{Structure and function of cartilage ECM molecules and their mutations in degenerative joint diseases}

Articular cartilage is an avascular aneural connective tissue composed of chondrocytes that produce and maintain a robust ECM protein network. During early bone development, mesenchymal stem cells of the chondrogenic progeny undergo differentiation into chondrocytes which proliferate, mature, and eventually calcify and undergo cell death as they are replaced by bone. This process leaves behind a layer of articullar cartilage that covers the surfaces of bones providing a low friction surface that can act as a weight/shear stress-bearing coat allowing for smooth joint transition during movement. Articular cartilage tissue has high water content contributing to its near frictionless nature.

\subsection{Collagens}

Articular cartilage ECM is composed mainly of three kinds of macromolecules: (1) collagens, (2) proteoglycans and (3) non-collagenous matrix proteins. Several collagens are cartilage specific including type II, VI, IX, X, and XI. Table 1 lists the most common cartilage ECM proteins and human diseases that result from their mutation, including their association with chondrodysplasia and OA.

\subsubsection{Collagen II}

Type II collagen makes up approximately 80 to 90 percent of all collagen content found in normal healthy articular cartilage tissue. In OA, tissue degradation is predominantly caused by the breakdown of cartilage ECM due to the overabundance of reactive proteases, many of which cleave type II collagen containing fibrils resulting in tissue destabilization due to reduction in tensile strength. Type II collagen is initially synthesized as pro-alpha-chains that are assembled into a triple helical structure by the globular domains that exist at both its $\mathrm{N}$ and $\mathrm{C}$ terminal ends. Two forms of pro-collagen are found in cartilage: Type IIA (COL2A1) and Type IIB. These trimeric type II collagen molecules crosslink with other collagens (i.e. type IX and XI) to form large fibrils that compose a web-like network, which binds to various ECM molecules. The stability of the triple helical structure provides the strength required by cartilage to resist tensile stress and also prevents type II collagen from being easily degraded by most endogenous proteases found in the tissue. Due to its long half-life (over 100 years under physiological conditions) and relative stability, the type II collagen network is never completely broken down or remodeled during normal cartilage homeostatic processes. Type II collagen mutations can cause a plethora of mild to severe phenotypes depending on the nature and location of the mutation. While heterozygous deletion of this gene in mice show a minimal phenotype, complete homozygous deletion predictably causes severe cartilage tissue disorganization and death shortly after birth (Li et al., 1995). In addition to being linked to the development of degenerative joint diseases such 


\begin{tabular}{|c|c|c|c|c|}
\hline Protein & Gene(s) & $\begin{array}{l}\text { Human diseases } \\
\text { caused by mutations }\end{array}$ & Chondrodysplasia & $\begin{array}{l}\text { OA } \\
\text { causative }\end{array}$ \\
\hline \multirow{5}{*}{$\begin{array}{l}\text { Type II } \\
\text { collagen }\end{array}$} & \multirow{5}{*}{ COL2A1 } & Stickler syndrome & Yes (mild) & May \\
\hline & & Achondrogenesis (type II) & Yes & $\begin{array}{l}\text { No } \\
\text { evidence }\end{array}$ \\
\hline & & Hypochondrogenesis & Yes & $\begin{array}{l}\text { No } \\
\text { evidence }\end{array}$ \\
\hline & & $\begin{array}{l}\text { Spondyloepiphyseal } \\
\text { dysplasia }\end{array}$ & Yes & May \\
\hline & & $\begin{array}{l}\text { Spondyloepimetaphyseal } \\
\text { dysplasia }\end{array}$ & Yes & May \\
\hline \multirow{2}{*}{$\begin{array}{l}\text { Type VI } \\
\text { collagen }\end{array}$} & \multirow{2}{*}{$\begin{array}{l}\text { COL6A1, } \\
\text { COL6A2, } \\
\text { COL6A3 }\end{array}$} & $\begin{array}{l}\text { Ullrich congenital muscular } \\
\text { dystrophy }\end{array}$ & No evidence & $\begin{array}{l}\text { No } \\
\text { evidence }\end{array}$ \\
\hline & & Bethlem myopathy & No evidence & $\begin{array}{l}\text { No } \\
\text { evidence }\end{array}$ \\
\hline \multirow{3}{*}{$\begin{array}{l}\text { Type IX } \\
\text { collagen }\end{array}$} & \multirow{3}{*}{$\begin{array}{l}\text { COL9A1, } \\
\text { COL9A2, } \\
\text { COL9A3 }\end{array}$} & $\begin{array}{l}\text { Multiple epiphyseal } \\
\text { dysplasia }\end{array}$ & Yes & May \\
\hline & & Lumbar disk disease & No evidence & $\begin{array}{l}\text { No } \\
\text { evidence }\end{array}$ \\
\hline & & Premature OA & No evidence & Yes \\
\hline \multirow{2}{*}{$\begin{array}{l}\text { Type X } \\
\text { collagen }\end{array}$} & \multirow{2}{*}{ COL10A1 } & $\begin{array}{l}\text { Schmid metaphyseal } \\
\text { dysplasia }\end{array}$ & Yes & $\begin{array}{l}\text { No } \\
\text { evidence }\end{array}$ \\
\hline & & $\begin{array}{l}\text { Spondylometaphyseal } \\
\text { dysplasia }\end{array}$ & Yes & May \\
\hline \multirow{3}{*}{$\begin{array}{l}\text { Type XI } \\
\text { collagen }\end{array}$} & \multirow{3}{*}{$\begin{array}{l}\text { COL11A1, } \\
\text { COL11A2 }\end{array}$} & Stickler syndrome & Yes (mild) & May \\
\hline & & $\begin{array}{l}\text { Spondylomegaepiphyseal } \\
\text { dysplasia }\end{array}$ & Yes & May \\
\hline & & Premature OA & No evidence & Yes \\
\hline Aggrecan & ACAN & Several chondrodysplasias & Yes & May \\
\hline \multirow{3}{*}{ Matrilin-3 } & \multirow{3}{*}{ MATN3 } & $\begin{array}{l}\text { Multiple epiphyseal } \\
\text { dysplasia }\end{array}$ & Yes & May \\
\hline & & $\begin{array}{l}\text { Spondyloepimetaphyseal } \\
\text { dysplasia }\end{array}$ & Yes & May \\
\hline & & Premature OA & No evidence & Yes \\
\hline \multirow{2}{*}{$\begin{array}{l}\text { Cartilage } \\
\text { oligomeric } \\
\text { matrix } \\
\text { protein }\end{array}$} & \multirow[b]{2}{*}{ COMP } & Pseudoachondroplasia & Yes & May \\
\hline & & $\begin{array}{l}\text { Multiple epiphyseal } \\
\text { dysplasia }\end{array}$ & Yes & May \\
\hline Lubricin & PRG4 & $\begin{array}{l}\text { Camptodactyly- } \\
\text { arthropathy-coxa vara- } \\
\text { pericarditis syndrome }\end{array}$ & No evidence & $\begin{array}{l}\text { No } \\
\text { evidence }\end{array}$ \\
\hline
\end{tabular}

Table 1. Cartilage matrix proteins and common human diseases associated with their mutation, including their association with chondrodysplasia and osteoarthritis (OA) 
as familial OA, various mutations in this molecule can cause more severe phenotypes such as Stickler syndrome, and several major chondrogenic defects (Byers, 2001). A mutation in the alpha helical domain causing a substitution of a glycine codon with a larger amino acid has been shown to disrupt proper alpha helix formation of type II collagen leading to severe chondrodysplasias and a significant reduction in cartilage tissue stability (Kuivaniemi et al., 1997; Prockop et al., 1997). Similarly in the 1990s, particular families were discovered to have missense mutation (R519C) causing the production of abnormal type II collagen pro-alphachains. These alpha chains formed protein dimers leading to mild chondrodysplasia followed by a unique form of familial OA (Byers, 2001; Eyre et al., 1991; Pun et al., 1994; Bleasel et al., 1998).

\subsubsection{Collagen XI}

Type XI collagen is the second most abundant collagen ( $3 \%$ of all collagens) found in adult articular cartilage and it is a core component of collagen fibrils. It is a heterotrimeric molecule composed of three alpha-chains. Interestingly, the first two chains are coded by the COL11A1 and COL11A2 genes respectively while the third chain is coded by COL2A1 and uniquely post transcriptionally modified (Martel-Pelletier et al., 2008). Type XI collagen makes hydroxylysine-based aldehyde cross-links with type II collagen to form collagen fibrils that stabilize articular cartilage (Cremer et al., 1988) and it has been suggested that the ratio of type XI to type II determines collagen fibril diameter and tensile strength. Like COL2A1, mutations in the type XI collagen genes can cause Stickler syndrome. A study done in 1995 also discovered that a single base pair deletion in the type XI collagen gene creates a frame shift resulting in a premature stop codon which is functionally equivalent to knocking out the gene itself ( $\mathrm{Li}$ et al., 1995). Mice that are homozygous for this nonsense mutation develop serious chondrodysplasia and die at birth. Missense mutations in the COL11A2 gene have also been associated with spondylo-megaepiphyseal dysplasia (OSMED) (Vikkula et al., 1995) and mutations in both COL11A1 and COL11A2 can cause premature development of OA (Rodriguez et al., 2004).

\subsubsection{Collagen IX}

Type IX collagen is normally co expressed with type II collagen in hyaline cartilage. In adults, this collagen makes up about $1 \%$ of the collagen content found in the articular cartilage. Similar to type VI collagen, type IX collagen molecules exist in heterotrimeric form composed of three alpha-chains. Each of these heterotrimers has seven sites with which to form cross-links with other collagen molecules. Type IX collagen is found to be covalently bonded through aldimine-derived crosslinks to the surface of large type II collagen fibrils (Wu et al., 1992) and it is believed to constrain the lateral expansion of these fibrils (Blaschke et al., 2000; Gregory et al., 2000). Missense mutations in the type IX collagen genes have been associated with lumbar disk disease (LDD) (Zhu et al., 2011) and multiple epiphyseal dysplasia (MED) (Jackson et al., 2010) which indirectly leads to the development of OA. Surprisingly, mice deficient in type IX collagen exhibit normal signs of skeletal and chondral development; however they are afflicted by early joint cartilage degradation that resemble the formation of OA-like lesions (Hu et al., 2006).

\subsubsection{Collagen VI}

Hyaline cartilage contains a relatively low content of type VI collagen (less than $2 \%$ of all articular cartilage tissue collagens) that is found in all cartilage zones within the pericellular 
regions around chondrocytes (Pullig et al., 1999). Type VI collagen molecules are of heterotrimeric organization as they are composed of three non-identical alpha chains. Each chain contains a triple helical domain allowing for the formation of dimers and tetramers with each other (Engel et al., 1985; Furthmayr et al., 1983). Type VI collagen interacts with non-collagenous matrix proteins forming a network in the pericellular regions. It has been previously demonstrated that type VI collagen content is increased in certain patients suffering from OA. However, it is suspected that disregulated tissue homeostasis causes excessive collagen anabolism and deposition (Pullig et al., 1999). Mutations in the genes that code for the three type VI collagen alpha chains have been associated with noncartilagespecific abnormalities such as muscular dystrophy (Pace et al., 2008) and Bethlem myopathy (Lamandé et al., 1998). And a study conducted in 2009 demonstrated that COL6A1 homozygous knockout mice display lower bone mineral density and develop OA more rapidly than wild-type mice of the same genetic background (Alexopoulos et al., 2009).

\subsubsection{Collagen X}

Chondrocytes only express type $X$ collagen within the hypertrophic zone of the growth plate (Linsenmayer et al., 1988). It is a homotrimer composed of three pro-alpha-chains each containing a $\mathrm{C}$ terminal alpha helical domain which allows these chains to assemble into short triple helixes (Wagner et al., 2000). It has been demonstrated that type $X$ collagen expression and distribution is altered during OA such that these molecules are found among the noncalcified regions of the articular cartilage implying the occurrence of premature chondrocyte hypertrophy in these zones (von der Mark et al., 1992). Abnormalities in type X collagen can cause spinal and metaphyseal dysplasias (i.e. Schmid MCD) due to improper enchondral ossification (Bignami et al., 1992). A heterozygous missence mutation (Gly595Glu) in the COL10A1 gene was also previously found to correlate with spondylometaphyseal dysplasia (SMD) within a certain family (Ikegawa et al., 1998). And transgenic mice with deletions in the triple-helical domain of type X collagen develop SMD (Jacenko et al., 1993).

\subsection{Proteoglycans}

The second major structural components of articullar cartilage tissue are proteoglycans of which aggrecan is the most common. These ECM proteins predominantly help cartilage tissue to retain water and withstand compressive force during joint transition and loading.

\subsubsection{Aggrecan}

Aggrecan is a large chondroitin sulfate proteoglycan that consists of a $220 \mathrm{kDa}$ protein core containing three globular domains (G1, G2 and G3) which allow it to form covalent bonds with its glycosaminoglycan (GAG) side chain components (Doege et al., 1991). Each GAG side chain is composed of a single keratin sulfate and two chondroitin sulfate domain regions all of which are adjacent to the G2 and G3 globular domains. The G1 domain is attached to a link protein that enables multiple aggrecan subunits to bind to a long nonsulfated glycosaminoglycan backbone known as hyluronic acid (HA). Thus aggrecan becomes trapped within the collagen network where some suspect that it acts to physically shield type II collagen from proteolytic cleavage (Pratta et al., 2003). Due to its overall negative charge, aggrecan draws water into the cartilage ECM allowing the tissue to swell. This swelling gives the tissue a spring-like quality helping it to withstand compressive 
forces that are applied to the joint during movement. Proteolytic cleavage of this vital ECM protein is mediated by proteases known as aggrecanases. During OA, the disregulation of aggrecanase synthesis and release causes much damage to aggrecan molecules and the cartilage tissue loses the ability to retain water as it suffers from a reduction in overall stability. As is the case with type II collagen and other major cartilage ECM proteins, deletions/mutations in aggrecan lead to severe chondrodysplasia which can often cause premature OA.

\subsubsection{Hyaluronic acid}

HA is a nonsulfated GAG that is covalently linked to aggrecan monomers and allows these subunits to aggregate in the cartilage ECM. HA species can have varying molecular mass depending on the length of the GAG. Their masses can range from as small as fifty to larger than thousands of Kilodaltons. The molecular weight of HA decreases during normal aging due to proteolytic cleavage and the cartilage tissue of young individuals tends to have larger species of HA compared to that of the elderly. In addition to the cartilage ECM, HA is also largely found in synovial fluid and contributes to its viscoelasticity. HA recognizes and specifically binds several different cell surface receptors (i.e. CD44, ICAM-1 and RHAMM) where it remains as a major component of the pericellular network surrounding chondrocytes. Due to its large size, HA can shield cells from coming into contact with inflammatory mediators such as cytokines and chemokines. It has also been suggested that HA can regulate collagenase and aggrecanase expression from chondrocytes and synovial cells. Previous studies have demonstrated that higher molecular mass species of HA can inhibit IL-1 mediated stimulation of certain MMPs and ADAMTS-4 by interacting with CD44 (Julovi et al., 2004; Wang et al., 2006; Theuns et al., 2008) while the opposite effect has been found to occur in the presence of smaller mass species $(20 \mathrm{kDa})$ of this proteoglycan. Additionally, these larger species can also inhibit proteoglycan release from cartilage tissue ECM. HA is currently used as an intra-articularly therapy via joint injection for knee OA as this long proteoglycan is believed to decrease OA associated joint pain by increasing both the viscoelastic properties of synovial fluid and the lubrication of the articular surface preventing tissue tearing due to the friction generated during joint transition. (Moreland, 2003; Wobig et al., 1998; Altman \& Moskowitz, 1998). Its efficacy in relieving OA related pain has been reported to be depend on the molecular mass of the HA chains as species of larger molecular mass were found to have a greater effect in reducing joint pain. Although the exact biological mechanism with which HA relieves OA associated joint pain remains to be elucidated, it is believed that this large proteoglycan supplements the natural synovial fluid increasing its viscoelasticity and reducing the friction generated during joint movement.

\subsubsection{Leucine-rich small proteoglycans}

Articullar cartilage also consists of a group of small proteoglycans classified for having seven to eleven leucine-rich repeats (SLRPs). The major cartilage SLRPs are decorin, biglycan, fibromodulin, lumican and epiphycan in the order of decreasing abundance. These small proteoglycans have several roles in maintaining cartilage tissue ECM organization and homeostasis such as interacting with various collagen species to strengthen the ECM network and protecting collagen fibrils from proteolytic cleavage by collagenases. The SLRPs decorin and biglycan are similar in structure as both consist of a leucine-rich core 
protein linked to either one (in the case of decorin) or two (in the case of biglycan) chondroitin/dermatan sulfate containing GAG chain(s). Previous literature has suggested that decorin can alter the cell cycle by modulating growth factor (i.e. TGF- $\beta$ and EGF) signaling and it is currently studied in cancer research. Although similar in structure to decorin, biglycan has a different physiological role in ECM. It has been suggested that this proteoglycan modulates BMP-4 signaling during osteoblast differentiation (Chen et al., 2004). Biglycan is essential during skeletal development to maintain normal bone mineral density. Fibromodulin and lumican are SLRPs that competitively bind the same region of collagen fibrils helping to regulate fibril diameter and ECM network assembly (Svensson et al. 2000). Epiphycan is a dermatan sulfate proteoglycan with seven leucine-rich repeats believed to maintain joint integrity, yet little is known about its function and the biological mechanism with which it protects tissue. Mutations and/or deletions in SLRP genes are associated primarily with connective tissue and eye disorders. One recent study demonstrated that biglycan and epiphycan double knockout mice are normal at birth but develop several skeletal abnormalities later in life along with premature OA (Nuka et al., 2010). But there have yet to be more studies that suggest abnormalities in these genes are linked to degenerative joint diseases. Given the importance of SLRPs in regulating tissue homeostasis and matrix organization, this is quite surprising.

\subsection{Non-collagenous matrix proteins}

Other important non-collagenous matrix proteins found in articular cartilage include the matrilins (matrilin-1 and -3), the cartilage oligomeric matrix protein (COMP), and the lubricating protein predominantly secreted by chondrocytes of the superficial zone: lubricin.

\subsubsection{Matrilins}

The matrilins are a family of noncollagenous oligomeric ECM proteins that are found in a broad range of tissues including articular cartilage and bone (Deak et al., 1999; Wagener et al., 1997; Piecha et al., 1999; Klatt et al., 2001). There are currently four known members within this family. MATN1 and MATN3 are cartilage specific while MATN2 and MATN4 are found in many connective tissue types (van der Weyden et al. 2006; Wu et al., 1998; Piecha et al., 2002). It has been demonstrated that matrilins form a filamentous network pericellularly in the cartilage ECM (Klatt et al., 2000). Structurally, MATN1 consists of two Von Willebrand Factor A (vWFA) domains, one epidermal growth factor-like (EGF) domain, so named because they share a forty amino-acid long residue commonly found in epidermal growth factor protein, and one alpha helical coil-coiled oligomerization domain. Each vWFA domain contains a metal ion-dependant adhesion site (MIDAS) and previous studies have demonstrated that its mutation can abolish filamentous network formation resulting in abnormal ECM assembly (Chen et al., 1999). Its coil-coiled oligomerization domain allows it to form homotrimers with other MATN1 molecules or hetero-oligomers with MATN3. MATN1 is expressed by post proliferative chondrocytes that constitute the zone of maturation within the growth plate. MATN1 interacts with both type II collagen and aggrecan playing a role in organizing fibril formation. MATN1 knockout mice exhibit abnormal fibrillogenesis as their collagen fibrils become aggregated in a uniform directional orientation as opposed to the normal matrix network-like organization observed in wildtype animals. 
Although mutations of MATN1 have not been associated with the development of degenerative joint diseases, MATN3 is the smallest and most recently discovered member of the matrilin family of ECM proteins. MATN3 contains a single vWFA domain, four EGF-like domains, and one alpha-helical oligomerization domain which allows it to form homooligomers with other MATN3 peptides and hetero-oligomers with MATN1 (Klatt et al., 2000). MATN3 is naturally found in the articular cartilage in its tetrameric form composed of four single oligomers covalently bound together by their alpha-helical oligomerization domains. Several known MATN3 mutations can lead to developmental abnormalities in articular cartilage and bone. These mutations can eventually either lead to OA directly, in the case of hand OA (Aeschlimann et al., 1993; Cepko et al., 1992) or indirectly, in the case of MED, which manifests with joint pain and early onset OA (Chen et al., 1992; Chen et al., 1993). A threonine to methionine missense mutation (T298M) in the first EGF-like domain of MATN3 has been found to correlate with the development of hand OA (Stefánsson et al., 2003) while a cystine to serine (C299S) missense mutation in this same region is common to many patients suffering from spondylo-epi-metaphyseal dysplasia (SEMD), which is a condition often leading to vertebral, epiphyseal/metaphyseal anomalies during development (Borochowitz et al., 2004). Likewise, an arginine to tryptophan missense mutation (R116W) in the vWFA domain has been associated with MED. It was discovered that this particular mutation prevents normal secretion of MATN3 from chondrocytes due to a dominant negative interaction between mutant and normal MATN3 quickly leading to an increase in MATN3 retention within the endoplasmic reticulum of these cells (Otten et al., 2005). Consequently, this reduction in the secretion of functional MATN3 is believed to contribute to MED. Interestingly, during advanced stages of OA, joint synovial fluid contains higher levels of cleaved ECM proteins including MATN3 oligomers due to the proteolysis of articular cartilage. One study has even shown that MATN3 mRNA is upregulated in some OA patients suggesting that the body may produce an excess of the protein (Pullig et al., 2002). Matrilin proteins are relatively well conserved between mice and humans making them ideal proteins to investigate in the mouse model. Complete homozygous deletion of the MATN3 gene in mice surprisingly results in no gross skeletal deformities at birth, but it does however result in the development of OA much earlier in life. MATN3 knockout mice were maintained in a C57BL/6J background and developed several signs of enhanced OA including osteophyte formation and the presence of large lesions in the superficial zone of the articular cartilage, which is the layer that is in direct contact with the knee joint synovium. Additionally, these knockout mice appear to have a higher bone mineral density (BMD) and lower overall cartilage proteoglycan content when compared to wild-type mice of the same genetic background. Perhaps the increase in BMD leads to over-loading of diarthroidial joints, which eventually manifests in the form of enhanced cartilage damage. Tentatively, MATN3's ability to prevent OA-like lesion formation in articular cartilage may also be related to its regulatory functions. The complete biological mechanism with which this ECM protein acts chondroprotectively remains to be elucidated.

\subsubsection{COMP}

Cartilage oligomeric matrix protein (COMP) is another non-collagenous ECM protein found in articular cartilage with a function that is not yet completely understood. It is a pentameric molecule which consists of five glycoprotein subunits held to one another by disulfide bonds. 
Each subunit contains an EGF-like domain and a thrombospondin-like domain. Previous studies have shown that COMP can stimulate type II collagen fibrillogenesis (Rosenberg et al., 1998). In cartilage, COMP is found bound to types I, II, and IX collagen molecules. While COMP knockout mice exhibit normal chondral and skeletal development, various missense mutation in the COMP gene have been shown to cause severe chondrodysplasias such as pseudoachondroplasia (PSACH) and MED, which is accompanied by premature OA development. COMP is also used as a marker of OA pathogenesis because its concentration is commonly elevated in OA patients (Williams \& Spector et al., 2008)

\subsubsection{Lubricin}

Lubricin is a large soluble proteoglycan that is highly expressed by synoviocytes and chondrocytes of superficial zone articular cartilage. It is found in the synovial fluid and it covers articular surfaces of joints acting as a lubricant that prevents friction induced tissue wear and tear during joint transition. Lubricin consists of a central core protein containing heavily glycosylated oligosaccharide side chains. The core protein contains two somatomedin B-like (SMB) domains, a single a hemopexin-like domain (PEX), and two glycosylated mucin-like domains (Rhee et al., 2005). It is coded by the PGR4 gene, which when knocked out results in cartilage degradation and synovial cell hyperplasia in mice. Mutations in this gene can cause camptodactyly-arthropathy-coxa vara-pericarditis syndrome (CACP), which is an autosomal recessive disease that causes synovial hyperplasia and joint degredation similar to the phenotype of mice that are completely deficient in this protein (Rhee et al., 2005).

\section{Extracellular matrix breakdown during osteoarthritis}

During cartilage turnover, ECM molecules are slowly broken down via proteolysis and replaced by newly synthesized ECM proteins secreted from nearby chondrocytes. The catabolic and anabolic processes of this turnover are balanced in normal cartilage so that the rate of proteolysis and ECM loss matches the rate of ECM synthesis. However, in OA cartilage, this balance is often observed to be shifted towards catabolism. Proteases act to degrade the ECM network by cleaving excessive amounts collagen and proteoglycans. These cleaved fragments are released into the cartilage matrix and some can even trigger further tissue catabolism by both known and unknown biological mechanisms. The degeneration of the joint cartilage is further enhanced by the lackluster process of tissue repair due to disregulated anabolism. During OA, the disregulation of common anabolic growth factors native to the articular cartilage (i.e. TGF- $\beta$, FGF and IGF) prevents adequate protection against the catabolic effects induced by proteases ultimately leading to an imbalanced cartilage turnover process that favors degradation.

\subsection{Activation of matrix proteases: MMPs, ADAMTS family}

$\mathrm{OA}$ is clinically characterized by its degenerative effect on major articular cartilage ECM components such as collagen fibrils and proteoglycans by proteolysis (Takaishi et al., 2008). This enhancement of articular cartilage ECM catabolism is mediated mostly by the matrix metalloproteinase (MMP) family of collagenases and the ADAMTS family of aggrecanases, which are often expressed by chondrocytes in response to inflammatory cytokines such as IL-1 $\beta$ (Martel-Pelletier et al., 2008; Glasson et al. 2005; Stanton et al., 
2005). MMPs are neutral zinc-dependent endoproteinases that, when activated, cleave and degrade ECM components during normal tissue turnover. The MMP family is divided into several categories based on their enzymatic activity: collagenases, gelatinases, stromelysins, and membrane-type MMPs (MT-MMPs). MMPs commonly involved in cartilage homeostasis are collagenases and gelatinases. Most MMPs are initially secreted as inactive pro-MMP proteins (zymogens) which are then activated by proteolytic cleavage themselves. Because of their catabolic activity, this family of proteases has received much attention in arthritis research. Both mRNA expression and enzymatic activity of certain metalloproteinase are increased in cartilage tissue during OA pathogenesis including: MMP-1 (Drummond et al., 1999), MMP-2 (Imai et al., 1997; Mohtai et al., 1993), MMP-3 (Okada et al., 1992), MMP-7 (Ohta et al., 1998), MMP-8 (Drummond et al., 1999), MMP-9 (Mohtai et al., 1993), MMP-10 and MMP-13 (Mitchell et al., 1996). Table 2 lists OA associated catabolic proteases and the matrix protein targets that they cleave.

\begin{tabular}{ll} 
OA associated proteinase & Matrix Substrate \\
\hline MMP-1 & $\begin{array}{l}\text { Types I, II, III, VII, VIII, X collagen } \\
\text { Aggrecan }\end{array}$ \\
\hline MMP-2 & $\begin{array}{l}\text { Types IV, V, VII, X collagen } \\
\text { Aggrecan, decorin }\end{array}$ \\
\hline MMP-3 & $\begin{array}{l}\text { Types II, III, IV, V, IX, X collagen } \\
\text { Aggrecan, decorin }\end{array}$ \\
\hline MMP-7 & $\begin{array}{l}\text { Types IV, X collagen } \\
\text { Aggrecan, versican }\end{array}$ \\
\hline MMP-8 & $\begin{array}{l}\text { Types I, II, III collagen } \\
\text { Aggrecan }\end{array}$ \\
\hline MMP-9 & $\begin{array}{l}\text { Types IV, V collagen } \\
\text { Decorin }\end{array}$ \\
\hline MMP-10 & $\begin{array}{l}\text { Types III, IV, V collagen } \\
\text { Aggrecan }\end{array}$ \\
\hline MMP-13 & $\begin{array}{l}\text { Types II, III, IV, IX, X collagen } \\
\text { Aggrecan }\end{array}$ \\
\hline ADAMTS-4 & $\begin{array}{l}\text { Aggrecan } \\
\text { Matrilin-3 }\end{array}$ \\
\hline ADAMTS-5 & Aggrecan \\
Brevican, matrilin-3
\end{tabular}

Table 2. Osteoarthritis (OA) associated MMPs and their cartilage extracellular matrix substrates.

\subsubsection{MMP-1}

MMP-1 is classified as a collagenase that shows preference for cleaving type III and type $\mathrm{X}$ collagens (Martel-Pelletier et al., 2008; Nwomeh et al., 2002) which, while not a major component of ECM, is still present in articular cartilage tissue. MMP-1 is stoichiometrically inhibited by tissue inhibitor of metalloproteinase (TIMP) 1 and 2 . 


\subsubsection{MMP-2}

MMP-2 (gelatinase A) is one of two gelatinases found in human tissues. It further degrades a broad range of collagen and proteoglycan species after these substrates have been initially cleaved by other protyolitic enzymes (i.e. collagenases and aggrecanases). During OA, most of the cartilage tissue damage caused by this metalloproteinase comes from its breakdown of aggrecan, decorin, type IV and X collagen. Active MMP-2 is present in superficial and transition zones of OA cartilage (Imai et al., 1997).

\subsubsection{MMP-3}

Similarly, MMP-3 is upregulated in early OA but mRNA levels subside during later stages. Immunohistochemical studies have previously demonstrated that MMP-3 is expressed primarily in the superficial and transition zone in early stage OA cartilage and MMP-3 staining positively correlates with tissue Mankin scores. In addition to degrading type IX collagen and certain proteoglycans (Martel-Pelletier et al., 2008; Okada et al., 1989), MMP-3 initiates a cascade that ultimately cleaves and activates pro-MMP-1.

\subsubsection{MMP-7}

Like MMP-2 and MMP-3, MMP-7 is mainly found in the superficial and transition zones of OA cartilage (Ohta et al., 1998). This metalloproteinase cleaves type IV and X collagens as well as various proteoglycans including aggrecan and versican. Additionally MMP-7 is involved in cleavage and activation of MMP-1, MMP-2, MMP-8 and MMP-9 pro-protein precursors (Dozier et al., 2006).

\subsubsection{MMP-8}

Unlike other OA associated metalloproteinases, MMP-8 is a collagenase that is produced by neutrophils in response to inflammatory cytokines. Although chondrocytes themselves produce very little of this catabolic enzyme (Stremme et al., 2003), inflammation of the synovium can cause the migration of neutrophils that synthesize and secrete it into and around the superficial zone of cartilage contributing to tissue destruction. MMP-8 cleaves type I, II, and III collagen species as well as various proteoglycans including aggrecan.

\subsubsection{MMP-9}

The second gelatinase common to human tissue is MMP-9 (gelatinase B) which prefers denatured collagen, mostly type IV and V, as a substrate for its catabolic activity (Okada et al., 1992). Its mRNA expression is minimal in normal articular cartilage but it is greatly elevated in fibrillated areas of OA cartilage.

\subsubsection{MMP-10}

MMP-10 is a collagenase that degrades collagens types III, IV, V and aggrecan (Nicholson et al., 1989; Fosang et al., 1991; Rechardt et al., 2000). It can also cleave and activate pro-MMP$1,-7,-8$ and -9 (Nakamura et al., 1998).

\subsubsection{MMP-13}

Although many members of the MMP family are involved in cartilage ECM catabolism, no other MMP is as damaging to cartilage tissue during OA as is the collagenase MMP-13. Type 
II collagen is the primary structural component of the articular cartilage ECM for which MMP-13 shows digestive preference over any other collagen type (Okada et al., 1992; Ohta et al., 1998). For this reason, it is the collagenase that causes the most cartilage ECM destruction during OA. In addition to type II collagen, it also cleaves type III, IV, IX and X collagen species endogenous to cartilage tissue. MMP-13 is normally expressed in many different tissues including skin, bone, muscle, and cartilage. Its expression normally coincides with type $X$ collagen expression in cartilage undergoing hypertrophic differentiation (Kamekura et al., 2005). In normal healthy cartilage, the primary role of MMP-13 is to enable hypertrophic zone expansion as it denatures pre-existing type II collagen fibrils of the ECM. However, it has been shown that overexpression of MMP-13 in articular chondrocytes also induces OA phenotypic changes (Mitchell et al., 1996). Previous studies have attempted to use MMP-13 inhibitors such as pyrimidinetrione analogs (Drummond et al., 1999) and benzofuran (Blagg et al., 2005) to remedy OA induced cartilage damage. However, their responsiveness was found to be dose dependant and often caused unwanted musculoskeletal side effects (Wu et al., 2005).

\subsubsection{Aggrecanases}

Aggrecanase-1 (ADAMTS-4) and aggrecanase-2 (ADAMTS-5) are known to be the two most active aggrecanases that lead to articular cartilage ECM catabolism during both OA and rheumatoid arthritis (RA) (Tortorella et al., 1999; Abbaszade et al., 1999). ADAMTS-4 and -5 act on a specific cleavage site (Glu 373/Ala 374) truncating these large proteoglycan chains (Kuno et al. 2000; Rodrı'quez-Manzaneque et al., 2002). In addition to their primary activity of aggrecan cleavage, they have also been shown to cleave MATN3 tetramers at the alphahelical oligomerization domain releasing MATN3 monomers into the extracellular space (Ahmad et al., 2009; Tahiri et al., 2008). Interestingly, a meniscal transaction induced OA model in mice showed that ADAMTS-5 KO mice sustain less damage to their articular cartilage than wild-type mice (Glasson et al., 2005) linking the expression of this aggrecanase to diminishing cartilage integrity.

\subsection{Release and function of cleaved matrix proteins}

Proteolytic cleavage of cartilage matrix constituents releases small oligomeric protein fragments into the extracellular space where they can mediate further tissue degradation. The release of oligomeric fragments produced during cleavage of ECM components such as fibronectin, HA, and type II collagen has previously been implicated in the enhancement of cartilage catabolism. Increasing concentrations of such fragments in synovial fluid samples of patients have been found to positively correlate with increasing grade of OA.

\subsubsection{Fibronectin cleavage fragments}

Fibronectin is a large $(450 \mathrm{kDa})$ adhesive glycoprotein found in many tissues throughout the body including articular cartilage. While native fibronectin normally plays a role in cell-tocell adhesion and migration, its smaller cleavage fragments (Fn-fs) have different properties and function. Due to enhanced proteolytic cleavage that characteristically occurs during OA and RA, elevated levels of Fn-fs (30 - $200 \mathrm{kDa})$ are commonly found in articular cartilage tissue and synovial fluid samples. Interestingly, injecting Fn-fs (but not native full length fibronectin) into the knees of rabbits causes up to a $50 \%$ depletion of total proteoglycan content in articular cartilage (Homandberg et al., 1993). These Fn-fs enhance the release of 
the catabolic cytokines: IL-1 $\alpha / \beta, \mathrm{TNF}-\alpha$, and IL-6, which greatly enhance the release of proMMP-2 and pro-MMP-3, while simultaneously suppressing the expression of aggrecan (Bewsey et al., 1996). The exact biological mechanism by which Fn-fs stimulate these catabolic effects is currently unknown however, the Fn-fs found in synovial fluid appear to bind and penetrate the articular cartilage surface of the superficial zone where they may then bind the fibronectin receptors of chondrocytes activating a cascade of events that result in the release of the aforementioned inflammatory cytokines (Xie \& Homandberg, 1993). This is further supported by the finding that competitive inhibition of Fn-fs binding to the fibronectin receptor prevents Fn-fs associated catabolic activity (Homandberg \& Hui, 1994).

\subsubsection{Hyaluronan cleavage fragments}

As previously discussed, injection of large molecular mass species of HA into the joint space of OA patients have been deemed therapeutic due to their pain relieving capabilities. However, cleavage of large HA species into smaller HA fragments (HA-fs) by proteolysis or oxidation generates oligomers that potentially have different properties than the original macromolecule (Soltés et al., 2007). CD44 is the primary cell membrane receptor that binds native HA. Adhesion to cells through CD44 allows HA to remain pericellular to chondrocytes where HA bound aggrecan aggregates can gather to draw water into the cartilage ECM giving the tissue compressive resistance required to withstand forces generated during joint loading and movement. However, HA-fs can competitively inhibit the interaction between CD44 and native high molecular weight HA species causing depletion of this (and other) proteoglycans within the cartilage ECM. Low mass $(<5 \mathrm{kDa})$ HA-fs can also induce MMP-3 and MMP-13 via Nf-kB activation by an unknown biological mechanism in explant culture experiments causing damage to cartilage tissue similar to the effect of Fn-fs. Additionally, HA-fs, but not native high molecular mass HA, have been known to activate iNOS in articular chondrocytes leading to enhanced production of NO ultimately causing further joint degredation.

\subsubsection{Collagen cleavage fragments}

During the normal pathophysiology of degenerative joint disease, type II collagen is also cleaved and partially degraded to produce smaller protein fragments with novel regulatory functions contributing to further tissue catabolism, as is the case with fibronectin and HA. Both the C-terminal and N-terminal ends of type II collagen monomers can be cleaved through proteolysis producing fragments termed CT and NT peptides, respectively. Such fragments have been shown to penetrate cartilage tissue and greatly enhance the mRNA expression of MMP-2, 3, 9, and 13 (Fichter et al., 2006) through MAPK p38 and NFKB signaling causing ECM breakdown and proteoglycan depletion (Guo et al., 2009). Similar to the way that HA-fs competitively inhibit HA interaction with CD44, it is surmised that type II collagen fragments can also bind chondrocyte cell membrane integrins preventing these receptors from interacting with type II collagen fibrils, thereby disrupting collagen network integrity. Annexin V is another chondrocyte cell membrane receptor that commonly interacts with native type II collagen. This interaction is vital for matrix vesicle mediated cartilage calcification. Like native type II collagen, the NT peptide can also regulate calcification by binding and activating this receptor. In high concentration, the NT peptide may potentially be responsible for pathological mineralization of the cartilage tissue as commonly seen in OA. 


\section{Extracellular matrix repair during osteoarthritis}

In addition to ECM degradation due to the presence of reactive proteases, as well as their catabolic by-products (such as cleaved matrix protein fragments), OA is also characterized by a disregulation of important structural proteins as well as several important growth factors and their respective antagonists. This altered anabolism is most likely a compensatory reaction by chondrocytes attempting to repair OA induced tissue damage. However, the enhanced expression of some anabolic factors can trigger significant changes to cartilage homeostasis exacerbating the situation.

\subsection{Altered expression of structural proteins}

While proteolytic processing of collagens is a common characteristic of OA, some of these structural proteins exhibit increased expression and synthesis during disease pathogenesis. Type II, and VI collagens are both highly expressed in OA cartilage. The increase in these native collagen species also provide substrates for proteolysis which generates collagen fragments that have catabolic properties that ultimately results in MMP and NO release followed by proteoglycan depletion, as discussed previously. It is understandable how such events can mediate further tissue degradation during OA. Additionally, the expression and spatial distribution of type $X$ collagen also changes in the OA joint. While typically type $X$ collagen expression is only localized to the calcified zone, which lies right above the subchondral bone, this marker is also expressed by middle zone cartilage during OA pathogenesis. The appearance of type $X$ collagen is often indicative of calcification, which seems to corroborate the increased tissue mineralization characteristic of later stages of this disease.

Although aggrecan expression is initially increased during early stage OA, during later stages of OA, its expression is downregulated in cartilage. Thus aggrecan depletion from cartilage tissue is not simply a result by ECM breakdown but it is also due to altered gene regulation. While the biological mechanism responsible for such alterations in gene regulation is not completely understood, it is at least partly due to cytokines and growth factors that are produced by chondrocytes, synoviocytes, and tissue localized immune cells during OA pathogenesis.

\subsection{Altered expression of growth factors}

The disregulation of potent growth factors during OA can significantly change tissue morphology.

\subsubsection{BMPs \& TGF- $\beta$}

While members of the bone morphogenic protein (BMP) family are present in low amounts in normal articular cartilage, their expression is altered during OA. Normally, BMP-2, 4, 6, 7, 9, and 13 are expressed in articular cartilage. These growth factors stimulate chondrocytes to synthesize ECM constituents such as aggrecan and type II collagen to undergo chondrogenic differentiation. They play a role in cartilage repair and help to maintain joint integrity. Some members of the family such as BMP-7 can even inhibit inflammatory cytokine induced MMP synthesis in chondrocytes and synoviocytes. This family of growth factors also has endogenous inhibitors known as BMP antagonists. BMP antagonists are a group of proteins that function by directly binding BMPs as to prohibit them from interacting with their cognate receptors. This effectively prevents BMP signaling. During 
OA, only BMP-2 is reported to be upregulated. However, BMP antagonists are also highly expressed in this disease. These antagonists alter normal cartilage homeostasis by inhibiting ECM anabolism mediated by all BMPs and significantly hindering cartilage tissue repair.

The expression and protein synthesis of the transforming growth factor beta (TGF- $\beta$ ) family are also altered during OA pathogenesis. Normal cartilage contains small amounts of these growth factors as they promote chondrocyte proliferation and chondrogenic differentiation. Similar to BMPs, they stimulate synthesis of ECM constituent proteins type II collagen and aggrecan. Additionally, TGF- $\beta$ inhibits the expression and synthesis of MMP-1 and MMP-9. However, the exact function of TGF- $\beta$ in the joint is still somewhat controversial due to its strong stimulation of MMP-13 and ADAMTS-4 expression in chondrocytes. OA cartilage displays a greater abundance of TGF- $\beta$ than seen in normal non-diseased cartilage. This is consistent with the increase of both MMP-13 and ADAMTS- 4 observed during disease progression. Inhibition of TGF- $\beta$ has also been shown effective in preventing osteophyte formation in OA cartilage explants suggesting that this growth factor may play a role in inhibiting chondrocyte hypertrophy and premature ossification characteristic of OA (Scharstuhl et al., 2002).

\subsubsection{IGFs, FGFs \& HGF}

Insulin-like growth factors (IGFs) and fibroblast growth factors (FGFs) are also two important proteins that are disregulated during OA. There are two types IGFs: IGF-1 and IGF-2. Both IGFs are present at higher levels in OA cartilage than normal. IGFs regulate homeostatic processes in many tissue types. In articular cartilage it promotes cell division, growth, and proteoglycan synthesis. A family of insulin-like growth factors binding proteins (IGFBPs) can modulate IGF activity by direct interaction. Out of the seven currently known IGFBPs (IGFBP1 to 7), IGFBP-3 is the most common protein to modulate IGF activity. It has been shown that IGFBP-3 can inhibit the activity of both IGF-1 and IGF-2 in a dose dependant manner (Devi et al., 2001). In articular cartilage, IGFBP-3 has been found to increase in abundance with age. During OA pathogenesis, IGFBP-3 levels are increased even further potentially hindering the process of tissue repair. Like IGFs, FGFs are also upregulated during OA. This family of proteins includes 22 currently identified members. In cartilage biology, the most studied members are FGF-2, FGF-9, and FGF-18 due to their strong stimulation of matrix synthesis and tissue repair. However, the role of these growth factors during OA progression remains to be elucidated. Hepatocyte growth factor (HGF) is another potent multifunctional mitogenic protein that is disregulated in OA cartilage. Deep zone cartilage tissue normally contains two different truncated HGF isoforms (NK1 and NK2) (Guévremont et al., 2003). Although full length HGF is not produced by chondrocytes, osteoblasts from the subchondral bone produce HGF which may be processed in the nearby tissue generating these truncated peptides which diffuse into the calcified and deep zones of cartilage. MMP-13 expression is enhanced by chondrocytes and synoviocytes that come into contact with HGF. Its increasing abundance in OA cartilage can potentially enhance collagen fibril catabolism. Interestingly, HGF is also known for its ability to induce angiogenesis. It is unclear whether this function directly exacerbates the inflammation commonly characteristic of degenerative joint diseases.

\section{Effect of major OA associated cytokines and chemokines on cartilage ECM}

Unlike RA, OA is not traditionally classified an inflammatory arthropathy. It is unclear if the inflammation is intrinsic to osteoarthritis or a manifestation of associated crystal (e.g., 
calcium pyrophosphate or hydroxyapatite) arthritis complicating the osteoarthritis. It is characterized by mild yet chronic inflammation that indirectly plays a significant role in disease progression and tissue destruction. Pro-inflammatory cytokine and chemokine production by mononuclear cells, cells of the synovial membrane, and articular chondrocytes can disrupt normal cartilage homeostasis favoring proteoglycan depletion and tissue destruction. The two main pro-inflammatory cytokines noted for their destructive effects during OA are IL-1 $\beta$ and TNF- $\alpha$.

\subsection{IL-1 $\beta$}

IL-1 $\beta$ is expressed and released mainly by synoviocytes and mononuclear cells during joint inflammation, but studies have shown that articular chondrocytes of OA cartilage too upregulate its expression and synthesis. IL-1 $\beta$ exerts several significant catabolic and antianabolic effects that make it the most disease causative cytokine in OA. It induces expression of the collagenases, especially MMP-1, MMP-3, MMP-9 and MMP-13, which are believed to contribute significantly to the enhancement of articular cartilage catabolism that occurs during OA (Martel-Pelletier et al., 2008). The IL-1 $\beta$ pathway ultimately activates nuclear factor- $\mathrm{kB}(\mathrm{NFKB})$, which is necessary for the transcription of many genes relevant to $\mathrm{OA}$ and joint inflammation including MMPs (Park et al., 2004). It has been shown in murine articular cartilage explants that suppressing MMP production via ІкB kinase inhibitiors is sufficient to reduce the degredation of both type II collagen and aggrecan (Pattoli et al., 2005).

The ability of IL-1 $\beta$ to downregulate the expression of type II collagen and aggrecan, the two main structural components of the articular cartilage ECM, further illustrates how this pathway can potentially hinder ECM repair in OA pathogenesis. It has been previously demonstrated that IL-1 $\beta$ induces a greater than twofold downregulation of both type II collagen and aggrecan expression in human chondrocytes (Toegal et al., 2008; Goldring et al., 1988). The production of type II collagen and aggrecan are important to the process of chondrogenesis during which mesenchymal stem cells of the chondrocyte lineage secrete the ECM protein components necessary to constitute articular cartilage. Even though chondrogenesis occurs primarily during development in humans, it can also be induced as a result of damage sustained to existing cartilage (as in the case of OA) (van Beuningen et al., 2000). IL-1 $\beta$ can inhibit chondrogenesis (Murakami et at., 2000) by downregulating the transcription factor SOX9 (Wehrli et al., 2003), which is a master regulator of the chondrogenesis pathway. Similarly, IL-1 $\beta$ downregulates the expression of certain TIMPs that normally bind and inhibit active MMPs (Martel-Pelletier et al., 2008). It is also known that the IL-1 receptor (IL-1RI) expression is higher in OA cartilage than in normal cartilage (Jacques et al., 2006) indicating the possibility that the IL-1 $\beta$ pathway is more active in OA chondrocytes. IL-1RI KO mice are resistant to the early development of OA (Jacques et al., 2006). All evidence point to IL-1 $\beta$ stimulation as a potential cause of articular cartilage ECM breakdown during OA. This is why it may be possible to regulate IL-1 $\beta$ activity, perhaps through endogenous pathway inhibition, to slow down OA development/progression.

\subsubsection{IL-1RI and IL-1RA}

The IL-1 $\beta$ pathway has several endogenous inhibitors (Martel-Pelletier et al., 2008; Arend et al., 2000). Normal signal transduction of this pathway is initiated upon ligand binding to the IL-1 receptor (IL-1RI). The ligand binding event enables IL-1RI to associate with another 
cell membrane bound protein known as the interleukin-1 receptor accessory protein (IL1RAcP), which is necessary for pathway activation (Wesche et al., 1997). The association of these two membrane bound proteins allows for cross phosphorylation to occur in their transmembrane signaling domains initiating the signaling cascade that eventually leads to transcription of the proteases and cytokines described previously. Interleukin-1 receptor II (IL-1RII) is a cell membrane bound protein which competes with IL-1RI for IL-1 ligand binding (Gabay et al., 2010). IL-1RII is an IL-1RI protein mimic that does not contain a transmembrane signaling domain therefore it will not initiate signal transduction of the pathway and it is classified as an IL-1 $\beta$ pathway inhibitor. Two other endogenous inhibitors of this pathway are known as soluble interleukin-1 receptor II (sIL-1RII) and soluble interleukin-1 receptor accessory protein (sIL-1RAcP) (Gabay et al., 2010). These proteins mimic IL-1RI and IL-1RAcP respectively. sIL-1RII competes with IL-1RI to bind IL-1 $\beta$, similarly sIL-1RAcP competes with IL-1RAcP to bind the IL-1RI.

The fifth, and arguable the most effective, inhibitor of this pathway is the IL-1RA. This protein is an IL-1 $\alpha / \beta$ protein mimic and binds IL-1RI with a much higher affinity than does either IL$1 \alpha$ or IL-1 $\beta$. IL-1RA bound IL-1RI cannot associate with IL-1RAcP and therefore is unable to initiate signal transduction of the IL-1 $\beta$ pathway. The IL-1RA gene can be alternatively spliced to form different isoforms. Currently four isoforms are known to exist in humans and two in mice. In humans, there are three intracellular isoforms of IL-RA (icIL-RA1, icIL-RA2, icIL-RA3) and one cell secreted isoform (sIL-1RA). The intracellular isoforms tend to be cell associated and stays in contact with the cell membrane of the cell from which it was produced. The secreted form of IL-1RA, however, can move into the extracellular space and proceed to inhibit the IL-1 $\beta$ signal transduction of cells that are further away. Several of these isoforms can be easily distinguished form one another due to their varying size: icIL-RA1/ icIL-RA2 (18-kDa), icIL-RA3 (16-kDa), and sIL-1RA (17-kDa) (Gabay et al., 2010).

IL-1RA is produced by many cell types including articular chondrocytes. It has been established that chondrocyte produced/secreted IL-1RA protein helps sustain articular cartilage integrity during both RA and OA induced inflammation. The later was demonstrated when chondrocytes taken from OA cartilage, which was transduced with IL-1RA, protected against IL-1-induced cartilage degradation in organ culture experiments (Baragi et al., 1995). Further support for the idea that IL-1RA is chondroprotective comes from IL-1RA knockout mice of multiple genetic backgrounds, which have been shown to develop early arthritis compared to wild-type mice of the same background (Arend et al., 2000). IL-RA knockout mice bred in both BALB/cA and MFIx129 backgrounds developed severe inflammatory arthritis. Additionally, IL-1 $\beta$ protein levels where elevated as high as three fold in these IL-1RA knock-out mice of both backgrounds while detectable levels of Bcells and T-cells remained constant between IL-1RA knock-out and wild-type mice (Nicklin et al., 2000).

In 1999, in vivo IL-1RA gene transfer experiments done in rabbits also demonstrated its potential to reduce OA severity. In these experiments, OA was artificially induced in the animals via meniscectomy after which local IL-1RA gene therapy by intra-articular plasmid injection was performed at 24 hour intervals 4 weeks post surgery. The animals were sacrificed exactly 4 weeks after the first injection and the joint synoviums were dissected and stained for IL-1RA. The level of IL-1RA present in the synoviums of these rabbits positively correlated with a reduction in articular cartilage lesions that resulted from OA indicating that IL-1RA was chondroprotective (Fernandes et al., 1999). A more recent study 
in 2005 looked at the levels of several potential chondrodestructive (IL-1a, IL-1 $\beta$, TNF- $\alpha$, etc.) as well as chondroprotective cytokines, one of which was sIL-1RA, in 31 patients who are at a higher risk of developing $\mathrm{OA}$ in one of their knees due to chronic anterior cruciate ligament (ACL) deficiency. This study found concentrations of IL-1 $\beta$ and TNF- $\alpha$ to be significantly higher in the ACL deficient vs. normal knees while the concentration of sIL1RA decreased with increasing grades of articular chondral damage (Marks et al., 2005). Finally, a 2008 randomized double-blinded cohort study done in 167 patients with knee OA looked at the symptomatic effect of chromium sulfate induced autologous IL-1RA production and found a significant reduction of OA induced pain in the treated patients based on Knee injury and Osteoarthritis Outcome Score (KOOS) and Knee Society Clinical Rating System .

It is important to note that the chondroprotective effects of IL-1RA during OA are only observable when the protein is consistently present in the joint synovium of the arthritic joint. This explains why short-lived drugs such as AnikinRA (Cohen, 2004), which only last 4 hours post-intraarticular injection into human patients (as determined by serum analysis) have limited efficacy in treating OA progression (Chevalier et al., 2009). This is also most likely the underlying reason behind the success of longer lasting treatment options such as gene therapy and other methods aimed at increasing autologous IL-1RA production within the synovium of the OA joint.

\subsection{TNF- $\alpha$}

Second only to IL-1 $\beta$, TNF- $\alpha$ is a potent pro-inflammatory cytokine responsible for initiating much joint destruction during OA and other such joint degenerative diseases. TNF- $\alpha$ is currently looked on as a potential target for late stage OA therapy as its appearance in the joint is a telltale sign of advanced severity of the disease. In late stage OA, both TNF-a and its p55 receptor undergoes increased expression by articular chondrocytes and synoviocytes enhancing TNF-a pathway signaling. This leads to increased production of NO, ECM degrading enzymes, especially the highly catabolic collagenases MMP-3 and MMP-13, and other inflammatory cytokines like IL-1 and IL-6, which overall off-balances tissue homeostasis favoring ECM destruction. TNF- $\alpha$ also enhances the synthesis and release of the prostaglandin PGE2, which inhibits chondrocyte differentiation and maturation while simultaneously promoting MMP production and IL-6 expression. Additionally, circulating mononuclear cells that are localized to areas of inflammation that have undergone OA induced tissue injury also release TNF-a worsening joint inflammation and ultimately further favoring catabolism. Although commercially available TNF- $\alpha$ inhibitors are most efficacious for relieving of RA associated joint inflammation, it has been demonstrated that certain inhibitors, such as infliximab and etanercept, can suppress NO production in human cartilage (Vuolteenaho et al., 2002) making them potentially effective for treating OA. Despite these findings, only a handful of clinical studies have delved into testing the efficacy of this approach to OA treatment.

\subsection{SDF-1}

Recently, SDF-1 has received attention in arthritis research. Patients suffering from OA and RA display an increase of this chemokine in their synovial fluid. Although no evidence suggests that chondrocytes produce SDF-1, superficial and deep zone chondrocytes do however express the SDF-1 receptor (CXCR4) (Kanbe et al., 2002). Both synovial fibroblasts 
and osteoblasts from the subchondral bone produce SDF-1 and so it is also found in the deep zone of cartilage tissue. During OA pathogenesis, macrophages and lymphoid cells that have been localized to the inflamed synovium and/or joint cartilage will produce this chemokine. Since SDF-1 is known for its strong chemotactic abilities attracting lymphocytes to the site of joint inflammation, it has been implicated in enhancing cartilage tissue catabolism. In addition to its chemotactic ability, SDF-1 also stimulates the production of MMP-3 and MMP-13 by interacting with the CXCR4 receptors of articular chondrocytes (Kanbe et al., 2002; Chiu et al., 2007) contributing to collagen and proteoglycan cleavage.

\section{Conclusion and future prospects in ECM biology and OA treatment}

There are no FDA approved drugs specific for the treatment of OA. Currently, the most effective interventions merely alleviate OA symptoms. The three main interventions available are: (1) Supplements that attempt to enhance the body's endogenous cartilage regenerative capabilities, (2) Drugs that attempt to reduce OA associated pain, and (3) Surgical interventions such as total joint replacement, which is currently the most effective form of relieving the pain and inflammation occuring during the more severe later stages of this degenerative joint disease. Today, total joint replacement is a commonly performed routine surgery. It offers significant and permanent pain relief that other alternative therapies cannot provide, but it remains to be the last resort for late stage OA sufferers.

The use of anti-cytokine therapy to prevent cartilage tissue destruction has recently received attention in OA research. As previously discussed, OA induced ECM destruction most closely associates with induction of the IL-1 $\beta$ and TNF- $\alpha$ pathways. These major inflammatory cytokines stimulate mononuclear cells, synovial fibroblasts, and articular chondrocytes to release IL-6, NO, and chemokines that enhance joint damage. They additionally disregulate the release of anabolic growth factors and tissue destructive proteolytic enzymes from chondrocytes causing major alteration in the process of cartilage homeostasis. Numerous in vitro and in vivo studies conducted in animal models show that using IL-1Ra protein to inhibit IL-1 $\beta$ pathway activation has promise for preventing OA induced ECM degradation and inflammation. However, in human studies, the efficacy of IL-1 pathway inhibition for the purpose of OA therapy has been somewhat less successful. A paper published in 2009 reported the short-term efficacy of treating OA patients with recombinant IL-1Ra protein (Anakinra), which is a anti-inflammatory drug initially approved by the FDA for the treatment of RA. In this randomized double-blinded study, 160 knee OA sufferers were given 50 to $150 \mathrm{mg}$ of Anakinra via intra-articular injection and their status was monitored for 4 weeks. During this time, knee joint pain was graded using the WOMAC pain index. Although there was no observable difference in cartilage destruction between the $150 \mathrm{mg}$ Anakinra and placebo injected groups, Anakinra did prove to reduce OA associated knee joint pain on the fourth day after treatment. However, given the short half-life of this recombinant protein (approximately 5 hours), it did not have a significant beneficial effect after the fourth day (Chevalier et al., 2009). Similarly, inhibition of IL-1 $\beta$ and IL-1 receptor expression using a synthetic anti-inflammatory analgesic molecule named Diacerein has proved to have similar pain relieving effects with the additional benefit of preventing ECM catabolism to some degree. This drug also seems to have longer lasting therapeutic effects than Anakinra due to its relative stability (Pelletier et al., 2000). 
As previously discussed, the intra-articular (or joint) injection of disease modifying ECM proteins such as lubricin and HA have been somewhat effective in reducing inflammation and tissue destruction. Similar use of various growth factors to repair OA induced ECM damage may be another promising avenue that warrants further investigation. Recent studies using "Preparations rich in growth factors" (PRGF), commonly consisting of platelet rich plasma (PRP), have demonstrated the efficacy of combining anabolic and anti-catabolic proteins to deliver a dual beneficial effect that reduces proteolytic ECM breakdown and promotes tissue repair in OA joints. Several studies conducted in the past decade have demonstrated that PRDF treatment reduces joint pain up to 5 weeks post injection while also showing signs that it may enhance regenerative capabilities of cartilage tissue. However, some of anabolic proteins used in these growth factor cocktails (i.e. TGF- $\beta$, IGF) are known to already be increased during OA pathogenesis. More studies need to be conducted in order to understand the mode by which such therapies are chondroprotective. Currently the use of PRP for the treatment of knee OA is in Phase 2 of clinical trials.

Localized intra-articular gene therapy is a very exciting and novel approach for treating degenerative joint diseases such as OA and RA. It provides a controlled method to sustain production of potentially therapeutic gene products that cannot be matched by more transient methods such as simple intra-articular injection. Sites of localized gene transfer include the synovium (most common target in past studies) as well as articular cartilage tissue itself. Thus far, gene candidates used for this approach include those that can potentially enhance ECM synthesis and repair and/or prevent ECM breakdown. IL-1Ra is an example of a chondroprotective gene that has been successfully utilized for gene transfer experiments in several animal models. These studies clearly show positive outcomes correlating with its expression within the joint including reduced inflammation and decreased tissue destruction (Calich et al., 2010). IGF-1 is another gene candidate that has been introduced into the knee joints of rabbits via adenovirus mediated gene transfer. These animals experienced enhanced ECM synthesis by the articular cartilage in their knee joints under both normal and inflamed conditions (Mi et al., 2000). The use of gene therapy for the treatment of $\mathrm{OA}$ has presented much promise; however, due to issues involving the practicality of its use, we are still a long time away from utilizing its full potential.

\section{References}

Abbaszade, I., Liu, RQ., Yang, F., Rosenfeld, SA., Ross, OH., Link, JR., et al. (1999). Cloning and characterization of ADAMTS11, an aggrecanase from the ADAMTS family. J. Biol. Chem., Vol. 274, No. 33, (August 1999), pp. 23443-23450. ISSN 0021-9258

Aeschlimann, D., Wetterwald, A., Fleisch, H. \& Paulsson, M. (1993). Expression of tissue transglutaminase in skeletal tissues correlates with events of terminal differentiation of chondrocytes. Journal of Cell Biology. Vol. 120, No. 6, (March 1993), pp. 1461-70, ISSN 0021-9525

Ahmad, R., Sylvester, J., Ahmad, M. \& Zafarullah, M. (2009) Adaptor proteins and Ras synergistically regulate IL-1-induced ADAMTS-4 expression in human chondrocytes. J. Immunol., Vol. 182, No.8 (April 2009), pp. 5081-5087, ISSN 15506606

Alexopoulos, LG., Youn, I., Bonaldo, P. \& Guilak F. (2009). Developmental and osteoarthritic changes in Col6a1-knockout mice: biomechanics of type VI collagen in the cartilage 
pericellular matrix. Arthritis Rheum., Vol. 60, No. 3, (March 2009), pp. 771-9, ISSN 0004-3591

Altman, RD. \& Moskowitz, R. (1998). Intraarticular sodium hyaluronate (Hyalgan) in the treatment of patients with osteoarthritis of the knee: a randomized clinical trial. Hyalgan Study Group. J Rheumatol. Vol. 25, No. 11, (November 1998), pp. 22032212. ISSN 0315-162X

Arend, WP. \& Gabay, C. (2000) Physiologic role of interleukin-1 receptor antagonist. Arthritis Res., Vol. 2, No. 4, (May 2000), pp. 245-248, ISSN 1465-9905

Baragi, VM., Renkiewicz, RR., Jordan, H., Bonadio, J., Hartman, JW. \& Roessler, BJ. (1995).Transplantation of transduced chondrocytes protects articular cartilage from interleukin 1-induced extracellular matrix degradation. J. Clin. Invest., Vol. 96, No. 5, (November 1995), pp. 2454-2460, ISSN 0021-9738

Bewsey, KE., Wen, C., Purple, C. \& Homandberg, GA. (1996). Fibronectin fragments induce the expression of stromelysin-1 mRNA and protein in bovine chondrocytes in monolayer culture. Biochim Biophys Acta., Vol. 1317, No. 1, (October 1996), pp. 55-64, ISSN 0006-3002

Bignami, A., Asher, R. \& Perides, G. (1992). The extracellular matrix of rat spinal cord: a comparative study on the localization of hyaluronic acid, glial hyaluronatebinding protein, and chondroitin sulfate proteoglycan. Exp Neurol., Vol. 117, No. 1, (July 1992), pp. 90-3, ISSN 0014-4886

Blagg, JA., Noe, MC., Wolf-Gouveia, LA., Reiter, LA., Laird, ER., Chang, SP., et al. (2005) Potent pyrimidinetrione- based inhibitors of MMP-13 with enhanced selectivity over MMP-14. Bioorg. Med. Chem. Lett., Vol. 15, No. 7 (April 2005), pp. 1807-1810, ISSN 0960-894X

Blaschke, UK., Eikenberry, EF., Hulmes, DJ., Galla, HJ. \& Bruckner, P. (2000). Collagen XI nucleates self-assembly and limits lateral growth of cartilage fibrils. J Biol Chem. Vol. 275, No. 14, (April 2000), pp. 10370-10378, ISSN 0021-9258

Bleasel ,JF., Holderbaum, D., Brancolini, V., Moskowitz, RW., Considine, EL., Prockop, DJ., et al. (1998). Five families with arginine 519-cysteine mutation in COL2A1: evidence for three distinct founders. Hum Mutat. Vol. 12, No. 3, (October 1998), pp. 172-176, ISSN 1059-7794

Borochowitz, ZU., Scheffer, D., Adir, V., Dagoneau, N., Munnich, A. \& Cormier-Daire, V. (2004) Spondylo-epi-metaphyseal dysplasia (SEMD) matrilin 3 type: homozygote matrilin 3 mutation in a novel form of SEMD. J. Med. Genet., Vol. 41, No. 5, (May 2004), pp. 366-372, ISSN 1468-6244

Byers, PH. (2001). Folding defects in fibrillar collagens. Philos Trans R Soc Lond B Biol Sci., Vol. 356, No. 1406, (February 2001), pp. 151-158, ISSN 0962-8436

Calich, AL., Domiciano, DS. \& Fuller, R. (2010). Osteoarthritis: can anti-cytokine therapy play a role in treatment? Clin Rheumatol. Vol. 29, No. 5, (January 2010), pp. 451-455, ISSN 1434-9949

Cepko, C. L. Transduction of genes using retrovirus vectors. In: Current Protocols in Molecular Biology, edited by A. F.M., R. Brent, R. Kingston, D. D. Moore, J. G. Seidman, J. A. Smith and K. Struhl. New York: Greene Publishing Associates, 1992, p. $9.10-9.14$. 
Chen, Q., Fitch, JM., Linsenmayer, C. \& Linsenmayer, TF. (1992) Type X collagen: covalent crosslinking to hypertrophic cartilage-collagen fibrils. Bone $\mathcal{E}$ Mineral. Vol. 17, No. 2, (May 1992), pp. 223-7, ISSN 0169-6009

Chen, Q., Fitch, JM., Gibney, E. \& Linsenmayer, TF. (1993). Type II collagen during cartilage and corneal development: immunohistochemical analysis with an anti- telopeptide antibody. Developmental Dynamics. Vol. 196, No. 1, (January 1993), pp. 47-53, ISSN 1058-8388

Chen, Q., Zhang, Y., Johnson, DM. \& Goetinck, PF. (1999). Assembly of a novel cartilage matrix protein filamentous network: molecular basis of differential requirement of von Willebrand factor A domains. Mol Biol Cell. Vol. 10, No. 7, (July 1999) pp. 21492162. ISSN 1059-1524

Chen, XD., Fisher, LW., Robey, PG. \& Young, MF. (2004). The small leucine-rich proteoglycan biglycan modulates BMP-4-induced osteoblast differentiation. FASEB J., Vol. 18, No. 9, (June 2004), pp. 948-58, ISSN 1530-6860

Chevalier, X., Goupille, P., Beaulieu, AD., Burch, FX., Bensen, WG., Conrozier, T. et al. (2009). Intraarticular injection of anakinra in osteoarthritis of the knee: a multicenter, randomized, double-blind, placebo-controlled study. Arthritis Rheum. Vol. 61, No. 3, (March 2009), pp. 344-352, ISSN 0004-3591

Chiu, YC., Yang, RS., Hsieh, KH., Fong, YC., Way, TD. \& Lee, TS., (2007). Stromal cellderived factor-1 induces matrix metalloprotease-13 expression in human chondrocytes. Mol Pharmacol., Vol. 72, No. 3, (September 2007), pp. 695-703, ISSN 0026-895X

Cohen, SB. (2004) The use of anakinra, an interleukin-1 receptor antagonist, in the treatment of rheumatoid arthritis. Rheum. Dis. Clin. N. Am., Vol. 30, No. 2 (May 2004), pp. 365-380, ISSN 0889-857X

Cremer, MA., Rosloniec, EF. \& Kang AH. (1988). The cartilage collagens: a review of their structure, organization, and role in the pathogenesis of experimental arthritis in animals and in human rheumatic disease. J Mol Med., Vol. 76, No. 3-4, (March 1988), pp. 275-88, ISSN 0946-2716

Deak, F., Wagener, R., Kiss, I. \& Paulsson, M. (1999). The matrilins: a novel family of oligomeric extracellular matrix proteins. Matrix Biol., Vol. 18, No. 1, (February 1999), pp.55-64, ISSN 0945-053X

Devi, GR., Graham, DL., Oh, Y. \& Rosenfeld, RG. (2001). Effect of IGFBP-3 on IGF- and IGFanalogue-induced insulin-like growth factor-I receptor (IGFIR) signaling. Growth Horm IGF Res., Vol. 11, No. 4, (August 2001), pp. 231-9, ISSN 1096-6374

Doege, KJ., Sasaki, M., Kimura, T. \& Yamada, Y. (1991). Complete coding sequence and deduced primary structure of the human cartilage large aggregating proteoglycan, aggrecan. Human-specific repeats, and additional alternatively spliced forms. J Biol Chem., Vol. 266, No. 2, (January 1991), pp. 894-902, ISSN 0021-9258

Dozier S., Escobar GP. \& Lindsey ML. (2006) Matrix metalloproteinase (MMP)-7 activates MMP-8 but not MMP-13. Med Chem. Vol. 2, No. 5, (September 2006), pp. 523-526, ISSN 1573-4064

Drummond, AH., Beckett, P., Brown, PD., Bone, EA., Davidson, AH., Galloway, WA., et al. (1999). Preclinical and clinical studies of MMP inhibitors in cancer. Ann N Y Acad Sci., Vol. 878, (June 1999), pp. 228-235, ISSN 0077-8923 
Engel, J., Furthmayr, H., Odermatt, E., von der Mark, H., Aumailley, M., Fleischmajer, R., et al. (1985). Structure and macromolecular organization of type VI collagen. Ann NY Acad Sci., Vol. 460, (December 1985), pp. 25-37, ISSN 0077-8923

Eyre, DR., Weis, MA., \& Moskowitz, RW. (1991). Cartilage expression of a type II collagen mutation in an inherited form of osteoarthritis associated with a mild chondrodysplasia. J Clin Invest., Vol. 87, No. 1, (January 1991), pp. 357-361, ISSN 0021-9738

Fernandes, J., Tardif, G., Martel-Pelletier, J., Lascau-Coman, V., Dupuis, M., Moldovan, F., et al. (1999) In vivo transfer of interleukin-1 receptor antagonist gene in osteoarthritic rabbit knee joints: prevention of osteoarthritis progression. Am. J. Pathol., Vol. 154, No. 4, (April 1999), pp.1159-1169, ISSN 0002-9440

Fichter, M., Korner, U., Schomburg, J., Jennings, L., Cole, AA., \& Mollenhauer, J. (2006). Collagen degradation products modulate matrix metalloproteinase expression in cultured articular chondrocytes. J Orthop Res. Vol. 24, No. 1, (January 2006), pp. 6370, ISSN 0736-0266

Fosang, AJ., Neame, PJ., Hardingham, TE., Murphy, G. \& Hamilton, JA. (1991). Cleavage of cartilage proteoglycan between G1 and G2 domains by stromelysins. J Biol Chem. Vol. 266, No. 24, (August 1991), pp. 15579-15582, ISSN 0021-9258

Furthmayr, H., Wiedemann, H., Timpl, R., Odermatt, E. \& Engel, J. (1983). Electronmicroscopical approach to a structural model of intima collagen. Biochem J. Vol. 211, No. 2, (May 1983), pp. 303-311, ISSN 0264-6021

Gabay, C., Lamacchia, C. \& Palmer, G. (2010). IL-1 pathways in inflammation and human diseases. Nat. Rev. Rheumatol., Vol. 6, No. 4, (April 2010), pp. 232-41, ISSN 17594804

Glasson, SS., Askew, R., Sheppard, B., Carito, B., Blanchet, T., Ma, HL., et al. (2005) Depletion of active ADAMTS5 prevents cartilage degradation in murine model of osteoarthritis. Nature. Vol. 434, No. 7033 (March 2005), pp. 644-648, ISSN 1476-4687

Goldring, MB., Birkhead, J., Sandell, LJ., Kimura, T. \& Krane, SM. (1988) Interleukin 1 suppresses expression of cartilage-specific types II and IX collagens and increases types I and III collagens in human chondrocytes. J. Clin. Invest.,Vol. 82, No. 6, (December 1988), pp. 2026-2037, ISSN 0021-9738

Goldring, MB. \& Marcu, KB. (2009). Cartilage homeostasis in health and rheumatic diseases. Arthritis Res Ther. Vol. 11, No. 3, (May 2009), pp. 224, ISSN 1478-6362

Gregory, KE., Oxford, JT., Chen, Y., Gambee, JE., Gygi, SP., Aebersold, R., et al. (2000). Structural organization of distinct domains within the non-collagenous $\mathrm{N}$-terminal region of collagen type XI. J Biol Chem. Vol. 275, No. 15, (April 2000), pp. 1149811506, ISSN 0021-9258

Guévremont, M., Martel-Pelletier, J., Massicotte, F., Tardif, G., Pelletier, JP., Ranger, P., et al. (2003). Human adult chondrocytes express hepatocyte growth factor (HGF) isoforms but not $\mathrm{HgF}$ : potential implication of osteoblasts on the presence of HGF in cartilage. J Bone Miner Res., Vol. 18, No. 6, (June 2003), pp. 1073-81, ISSN 08840431

Guo, D., Ding, L. \& Homandberg, GA. (2009). Telopeptides of type II collagen upregulate proteinases and damage cartilage but are less effective than highly active fibronectin fragments. Inflamm Res., Vol. 58, No. 3, (March 2009), pp. 161-9, ISSN 1420-908X 
Homandberg, GA., Meyers, R. \& Williams, JM. (1993). Intraarticular injection of fibronectin fragments causes severe depletion of cartilage proteoglycans in vivo. J Rheumatol. Vol. 20, No. 8, (August 1993), pp. 1378-1382, ISSN 0315-162X

Homandberg, GA. \& Hui, F. (1994). Arg-Gly-Asp-Ser peptide analogs suppress cartilage chondrolytic activities of integrin-binding and nonbinding fibronectin fragments. Arch Biochem Biophys. Vol. 310, No. 1, (April 1994), pp. 40-48, ISSN 0003-9861

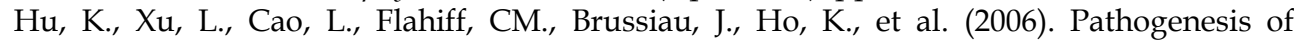
osteoarthritis-like changes in the joints of mice deficient in type IX collagen. Arthritis Rheum. Vol. 54, No. 9, (September 2006), pp. 2891-2900, ISSN 0004-3591

Ikegawa, S., Nishimura, G., Nagai, T., Hasegawa, T., Ohashi, H., Nakamura, Y. et al. (1998). Mutation of the type $\mathrm{X}$ collagen gene (COL10A1) causes spondylometaphyseal dysplasia. Am J Hum Genet., Vol. 63, No. 6, (December 1998), pp. 1659-62, ISSN 0002-9297

Imai, K., Ohta, S., Matsumoto, T., Fujimoto, N., Sato, H., Seiki, M., et al. (1997). Expression of membrane-type 1 matrix metalloproteinase and activation of progelatinase A in human osteoarthritic cartilage. Am. J. Pathol., Vol. 15, No. 1, (July 1997), pp. 245256, ISSN 0002-9440

Jacenko O, LuValle PA \& Olsen BR. (1993). Spondylometaphyseal dysplasia in mice carrying a dominant negative mutation in a matrix protein specific for cartilage-to-bone transition. Nature. Vol. 365, No. 6441, (September 1993), pp. 56-61, ISSN 0028-0836

Jackson, GC., Marcus-Soekarman, D., Stolte-Dijkstra, I., Verrips, A., Taylor, JA. \& Briggs, MD. (2010). Type IX collagen gene mutations can result in multiple epiphyseal dysplasia that is associated with osteochondritis dissecans and a mild myopathy. Am J Med Genet A., Vol. 152A, No. 4, (April 2010), pp. 863-9, ISSN 1552-4833

Jacques, C., Gosset, M., Berenbaum, F. \& Gabay, C. (2006). The role of IL-1 and IL-1Ra in joint inflammation and cartilage degradation. Vitam. Horm., Vol. 74, (December 2006), pp. 371-403, ISSN 0083-6729

Julovi, SM., Yasuda, T., Shimizu, M., Hiramitsu, T., \& Nakamura, T. (2004). Inhibition of interleukin-1beta-stimulated production of matrix metalloproteinases by hyaluronan via CD44 in human articular cartilage. Arthritis Rheum. Vol. 50, No. 2, (February 2004), pp. 516-525, ISSN 0004-3591

Kamekura, S., Hoshi, K., Shimoaka, T., Chung, U., Chikuda, H., Yamada, T., et al. (2005) Osteoarthritis development in novel experimental mouse models induced by knee joint instability. Osteoarthritis Cartil., Vol. 13, No. 7 (July 2005), pp. 632-641, ISSN 1063-4584

Kanbe, K., Takagishi, K. \& Chen, Q. (2002). Stimulation of matrix metalloprotease 3 release from human chondrocytes by the interaction of stromal cell-derived factor 1 and CXC chemokine receptor 4. Arthritis Rheum., Vol. 46, No. 1, (January 2002), pp. 130-7, ISSN 0004-3591

Klatt, AR., Nitsche, DP., Kobbe, B., Mörgelin, M., Paulsson, M. \& Wagener, R. (2000) Molecular structure and tissue distribution of matrilin-3, a filament-forming extracellular matrix protein expressed during skeletal development. Journal of Biological Chemistry. Vol. 275, No. 6, (February 2000), pp. 3999-4006, ISSN 00219258 
Klatt, AR., Nitsche, DP., Kobbe, B., Macht, M., Paulsson, M. \& Wagener, R. (2001). Molecular structure, processing, and tissue distribution of matrilin-4. J. Biol. Chem., Vol. 276, No. 20, (May 2001), pp. 17267-17275, ISSN 0021-9258

Kuivaniemi, H., Tromp, G., \& Prockop, DJ. (1997). Mutations in fibrillar collagens (types I, II, III, and XI), fibril-associated collagen (type IX), and network-forming collagen (type $\mathrm{X}$ ) cause a spectrum of diseases of bone, cartilage, and blood vessels. Hum Mutat., Vol. 9, No. 4, (June 1997), pp. 300-315, ISSN 1059-7794

Kuno, K., Okada, Y., Kawashima, H., Nakamura, H., Miyasaka, M., Ohno, H., et al. (2000) ADAMTS-1 cleaves a cartilage proteoglycan, aggrecan. FEBS Lett., Vol. 478, No. 3 (August 2000), pp. 241-245, ISSN 0014-5793

Lamandé, SR., Bateman, JF., Hutchison, W., McKinlay Gardner, RJ., Bower, SP., Byrne E., et al. (1998). Reduced collagen VI causes Bethlem myopathy: a heterozygous COL6A1 nonsense mutation results in mRNA decay and functional haploinsufficiency. Hum Mol Genet., Vol. 7, No. 6 (June 1998), pp. 981-9, ISSN 0964-6906

Li, SW., Prockop, DJ., Helminen, H., Fässler, R., Lapveteläinen, T., Kiraly, K., et al. (1995). Transgenic mice with targeted inactivation of the Col2 alpha 1 gene for collagen II develop a skeleton with membranous and periosteal bone but no endochondral bone. Genes Dev., Vol. 9, No. 22, (November 1995), pp. 2821-2830, ISSN 0890-9369

Li, Y., Lacerda, DA., Warman, ML., Beier, DR., Yoshioka, H., Ninomiya, Y., et al. (1995). A fibrillar collagen gene, Col11a1, is essential for skeletal morphogenesis. Cell, Vol. 80, No. 3, (February 1995), pp. 423-30, ISSN 0092-8674

Linsenmayer, TF., Eavey, RD. \& Schmid, TM. (1988). Type X collagen: a hypertrophic cartilage-specific molecule. Pathol Immunopathol Res., Vol. 7, No. 1-2, (1988), pp. $14-$ 9, ISSN 0257-2761

Marks, PH. \& Donaldson, ML. (2005) Inflammatory cytokine profiles associated with chondral damage in the anterior cruciate ligament-deficient knee. Arthroscopy. Vol. 21, No. 11, (November 2005), pp.1342-1347, ISSN 1526-3231

Martel-Pelletier, J., Boileau, C., Pelletier, JP. \& Roughley, PJ. (2008). Cartilage in normal and osteoarthritis conditions. Best Pract Res Clin Rheumatol. Vol. 22, No. 2, (April 2008), pp. 351-384, ISSN 1521-6942

Mi, Z., Ghivizzani, SC., Lechman, ER., Jaffurs, D., Glorioso, JC., Evans, CH. et al. (2000). Adenovirus-mediated gene transfer of insulin-like growth factor 1 stimulates proteoglycan synthesis in rabbit joints. Arthritis Rheum. Vol. 43, No. 11, (November 2000), pp. 2563-2570, ISSN 0004-3591

Mitchell, PG., Magna, HA., Reeves, LM., Lopresti-Morrow, LL., Yocum, SA., Rosner, PJ., et al. (1996) Cloning, expression, and type II collagenolytic activity of matrix metalloproteinase-13 from human osteoarthritic cartilage. J. Clin. Invest., Vol. 97, No. 3 (February 1996), pp. 761-768, ISSN 0021-9738

Mohtai,M., Smith, RL., Schurman, DJ., Tsuji, Y., Torti, FM., Hutchinson, NI., et al. (1993). Expression of 92-kD type IV collagenase/gelatinase (gelatinase B) in osteoarthritic cartilage and its induction in normal human articular cartilage by interleukin $1 . \mathrm{J}$. Clin. Invest., Vol. 92, No. 1, (July 1993), pp. 179-185, ISSN 0021-9738

Moreland, LW . (2003). Intra-articular hyaluronan (hyaluronic acid) and hylans for the treatment of osteoarthritis: mechanisms of action. Arthritis Res Ther. Vol 5, No. 2, (January 2003), pp. 54-67. ISSN 1478-6362 
Murakami ,S., Lefebvre, V. \& de Crombrugghe, B. (2000). Potent Inhibition of the Master Chondrogenic FactorSox9 Gene by Interleukin-1 and Tumor Necrosis Factor-a. J. Biol. Chem., Vol. 275, No. 5, (February 2000), pp. 3687-92, ISSN 0021-9258

Nakamura, H., Fujii, Y., Ohuchi, E., Yamamoto, E. \& Okada, Y. (1998). Activation of the precursor of human stromelysin 2 and its interactions with other matrix metalloproteinases. Eur J Biochem. Vol. 253, No. 1, (April 1998), pp. 67-75, ISSN 0014-2956

Nicholson, R., Murphy, G. \& Breathnach R. (1989). Human and rat malignant-tumorassociated mRNAs encode stromelysin-like metalloproteinases. Biochemistry. Vol. 28, No. 12, (June 1989), pp. 5195-5203, ISSN 0006-2960

Nicklin, MJ., Hughes, DE., Barton, JL., Ure, JM. \& Duff, GW. (2000) Arterial inflammation in mice lacking the interleukin 1 receptor antagonist gene. J. Exp. Med., Vol. 191, No. 2 (January 2000), pp. 303-312, ISSN 0022- 1007

Nuka, S., Zhou, W., Henry, SP., Gendron, CM., Schultz, JB., Shinomura, T., et al. (2010). Phenotypic characterization of epiphycan-deficient and epiphycan/biglycan double-deficient mice. Osteoarthritis Cartilage. Vol. 18, No. 1, (January 2010), pp. 88-96, ISSN 1522-9653

Nwomeh, BC., Liang, HX., Diegelmann, RF., Cohen, IK. \& Yager, DR. (2002) Dynamics of the matrix metalloproteinases MMP-1 and MMP-8 in acute open human dermal wounds. Wound Repair and Regeneration. Vol. 6, No. 2, (March-April 2002), pp. 127134, ISSN 1067-1927

Ohta, S., Imai, K., Yamashita, K., Matsumoto, T., Azumano, I. \& Okada, Y. (1998) Expression of matrix metalloproteinase 7 (matrilysin) in human osteoarthritic cartilage. Lab. Invest., Vol. 78, No. 1, (January 1998), pp. 79-87, ISSN 0023-6837

Okada, Y., Konomi, H., Yada, T., Kimata, K., and Nagase, H. (1989). Degradation of type IX collagen by matrix metalloproteinase 3 (stromelysin) from human rheumatoid synovial cells. FEBS Lett., Vol. 244, No. 2, (February 1989), pp. 473-476, ISSN 0014-5793

Okada, Y., Shinmei, M., Tanaka, O., Naka, K., Kimura, A., Nakanishi, I., et al. (1992). Localization of matrix metalloproteinase 3 (stromelysin) in osteoarthritic cartilage and synovium. Lab. Invest., Vol. 66, No. 6, (June 1992), pp. 680-690, ISSN 00236837

Otten, C., Wagener, R., Paulsson, M. \& Zaucke, F. (2005) Matrilin-3 mutations that cause chondrodysplasias interfere with protein trafficking while a mutation associated with hand osteoarthritis does not. J. Med. Genet., Vol. 42, No. 10, (October 2005), pp. 774-779, ISSN 1468-6244

Pace, RA., Peat, RA., Baker, NL., Zamurs, L., Mörgelin, M., Irving, M., et al. (2008). Collagen VI glycine mutations: perturbed assembly and a spectrum of clinical severity. Ann Neurol., Vol. 64, No. 3, (September 2008), pp. 294-303, ISSN 1531-8249

Park, MY., Jang, HD., Lee, SY., Lee, KJ. \& Kim, E. (2004). Fas-associated factor-1 inhibits nuclear factor-kappaB (NF-kappaB) activity by interfering with nuclear translocation of the RelA (p65) subunit of NF-kappaB. J Biol Chem. Vol. 279, No. 4, (January 2004), pp. 2544-2549, ISSN 0021-9258

Pattoli, MA., MacMaster, JF., Gregor, KR. \& Burke, JR. (2005) Collagen and aggrecan degradation is blocked in interleukin-1-treated cartilage explants by an inhibitor of 
IkappaB kinase through suppression of metalloproteinase expression. J. Pharmacol. Exp. Ther., Vol. 315, No. 1, (October 2005), pp. 382-388, ISSN 0022-3565

Pelletier, JP., Yaron, M., Haraoui, B., Cohen, P., Nahir, MA., Choquette, D. et al. (2000). Efficacy and safety of diacerein in osteoarthritis of the knee: a double-blind, placebo-controlled trial. The Diacerein Study Group. Arthritis Rheum. Vol. 43, No. 10, (October 2000), pp. 2339-2348, ISSN 0004-3591

Piecha, D., Muratoglu, S., Mörgelin, M., Hauser, N., Studer, D., Kiss, I. et al. (1999) Matrilin2, a large, oligomeric matrix protein, is expressed by a great variety of cells and forms fibrillar networks. J. Biol. Chem., Vol. 274, No. 19, (May 1999), pp. 1335313361, ISSN 0021-9258

Piecha, D., Hartmann, K., Kobbe, B., Haase, I., Mauch, C., Krieg, T., et al. (2002) Expression of Matrilin-2 in Human Skin. Journal of Investigative Dermatology. Vol. 119, No. 1 (July 2002), pp. 38-43. ISSN 0022-202X

Pratta, MA., Yao, W., Decicco, C., Tortorella, MD., Liu, RQ., Copeland, RA., et al. (2003). Aggrecan protects cartilage collagen from proteolytic cleavage. J Biol Chem., Vol. 278, No. 46, (November 2003), pp. 45539-45, ISSN 0021-9258

Prockop, DJ., Ala-Kokko, L., McLain, DA., \& Williams, C. (1997). Can mutated genes cause common osteoarthritis? Br J Rheumatol., Vol. 36, No. 8, (August 1997), pp. 827-829, ISSN 0263-7103

Pullig, O., Weseloh, G. \& Swoboda, B. (1999). Expression of type VI collagen in normal and osteoarthritic human cartilage. Osteoarthritis Cartilage, Vol. 7, No. 2, (March 1999), pp. 191-202, ISSN 1063-4584

Pullig, O., Weseloh, G., Klatt, AR., Wagener, R. \& Swoboda, B. (2002) Matrilin-3 in human articular cartilage: increased expression in osteoarthritis. Osteoarthritis Cartilage., Vol. 10 No. 4, (April 2002) pp. 253-263, ISSN 1063-4584

Pun, YL., Moskowitz, RW., Lie, S., Sundstrom, WR., Block, SR., McEwen, C., et al. (1994). Clinical correlations of osteoarthritis associated with a single-base mutation (arginine519 to cysteine) in type II procollagen gene. A newly defined pathogenesis. Arthritis Rheum. Vol. 37, No. 2, (February 1994), pp. 264-269, ISSN 0004-3591

Rechardt, O., Elomaa, O., Vaalamo, M., Pääkkönen, K., Jahkola, T., Höök-Nikanne, J., et al. (2000). Stromelysin-2 is upregulated during normal wound repair and is induced by cytokines. J Invest Dermatol. Vol. 115, No. 5, (November 2000), pp. 778-787, ISSN 0022-202X

Rhee, DK., Marcelino, J., Al-Mayouf, S., Schelling, DK., Bartels, CF., Cui, Y., et al. (2005). Consequences of disease- causing mutations on lubricin protein synthesis, secretion, and post-translational processing. J Biol Chem., Vol. 280, No. 35, (September 2005), pp. 31325-32, ISSN 0021-9258

Rodriguez, RR., Seegmiller, RE., Stark, MR. \& Bridgewater, LC. (2004). A type XI collagen mutation leads to increased degradation of type II collagen in articular cartilage. Osteoarthritis Cartilage, Vol. 12, No. 4, (April 2004), pp. 314-20, ISSN 1063-4584

Rodríguez-Manzaneque, JC., Westling, J., Thai, SN., Luque, A., Knauper, V., Murphy, G., et al. (2002) ADAMTS1 cleaves aggrecan at multiple sites and is differentially inhibited by metalloproteinase inhibitors. Biochem. Biophys. Res. Commun., Vol. 293, No. 1, (April 2002), pp. 501-508, ISSN 0006-291X 
Rosenberg ,K., Olsson, H., Mörgelin, M. \& Heinegård, D. (1998). Cartilage oligomeric matrix protein shows high affinity zinc-dependent interaction with triple helical collagen. J Biol Chem., Vol. 273, No. 32, (August 1998), pp. 20397-403, ISSN 00219258

Scharstuhl, A., Glansbeek, HL., van Beuningen, HM., Vitters, EL., van der Kraan, PM. \& van den Berg, WB. (2002). Inhibition of endogenous TGF-beta during experimental osteoarthritis prevents osteophyte formation and impairs cartilage repair. $J$ Immunol., Vol. 169, No. 1, (July 2002), pp. 507-14, ISSN 0022-1767

Soltés, L., Kogan, G., Stankovska, M., Mendichi, R., Rychlý, J., Schiller, J., et al. (2007). Degradation of high-molar-mass hyaluronan and characterization of fragments. Biomacromolecules., Vol. 8, No. 9, (September 2007), pp. 2697-705, ISSN 1525-7797

Stanton, H., Rogerson, FM., East, CJ., Golub, SB., Lawlor, KE., Meeker, CT., et al. (2005) ADAMTS5 is the major aggrecanase in mouse cartilage in vivo and in vitro. Nature. Vol. 434, No. 7033, (March 2005), pp. 648-652, ISSN 1476-4687

Stefánsson, SE., Jónsson, H., Ingvarsson, T., Manolescu, I., Jónsson, HH., Olafsdóttir, G., et al. (2003) Genomewide scan for hand osteoarthritis: a novel mutation in matrilin-3. Am. J. Hum. Genet., Vol. 72, No. 6, (June 2003), pp.1448-1459, ISSN 0002-9297

Stremme, S., Duerr, S., Bau, B., Schmid, E. \& Aigner, T. (2003). MMP-8 is only a minor gene product of human adult articular chondrocytes of the knee. Clin Exp Rheumatol., Vol. 21, No. 2, (March-April 2003), pp. 205-9, ISSN 0392-856X

Svensson, L., Närlid, I. \& Oldberg, A. (2000). Fibromodulin and lumican bind to the same region on collagen type I fibrils. FEBS Lett., Vol. 470, No. 2, (March 2000), pp. 17882, ISSN 0014-5793

Tahiri, K., Korwin-Zmijowska, C., Richette, P., Héraud, F., Chevalier, X., Savouret, JF., et al. (2008) Natural chondroitin sulphates increase aggregation of proteoglycan complexes and decrease ADAMTS- 5 expression in interleukin 1 beta-treated chondrocytes. Ann. Rheum. Dis., Vol. 67, No. 5, (May 2008), pp. 696-702, ISSN 14682060

Takaishi, H., Kimura, T., Dalal, S., Okada, Y. \& D'Armiento, J. (2008) Joint diseases and matrix metalloproteinases: a role for MMP-13. Current Pharm. Biotech., Vol. 9, No. 1 (February 2008), pp. 47-54, ISSN 1873-4316

Theuns, DA., Rivero-Ayerza, M., Goedhart, DM., Miltenburg, M. \& Jordaens, LJ. (2008). Morphology discrimination in implantable cardioverter-defibrillators: consistency of template match percentage during atrial tachyarrhythmias at different heart rates. Europace., Vol. 10, No. 9, (September 2008), pp. 1060-6, ISSN 1532-2092

Toegel, S., Wu, SQ., Piana, C., Unger, FM., Wirth, M., Goldring, MB., et al. (2008) Comparison between chondroprotective effects of glucosamine, curcumin, and diacerein in IL-1 $\beta$-stimulated C-28/I2 chondrocytes. Osteoarthritis and Cartilage. Vol. 16, No. 10, (October 2008), pp. 1205-1212, ISSN 1522-9653

Tortorella, MD., Burn, TC., Pratta, MA., Abbaszade, I., Hollis, JM., Liu ,R., et al. (1999) Purification and cloning of aggrecanase-1: amember of the ADAMTS family of proteins. Science.Vol. 284, No. 5420, (June 1999), pp.1664-1666, ISSN 0036-8075

van Beuningen, HM., Glansbeek, HL., van der Kraan, PM. \& van den Berg, WB. (2000) Osteoarthritis-like changes in the murine knee joint resulting from intra-articular transforming growth factor-beta injections. Osteoarthritis and Cartilage. Vol. 8, No. 1, (January 2000), pp. 25-33, ISSN 1063-4584 
van der Weyden, L., Wei, L., Luo, J., Yang, X., Birk, DE., Adams, DJ., et al. (2006) Functional knockout of the matrilin- 3 gene causes premature chondrocyte maturation to hypertrophy and increases bone mineral density and osteoarthritis. American Journal of Pathology. Vol. 169, No. 2, (August 2006), pp. 515-527, ISSN 0002-9440

Vikkula, M., Mariman, EC., Lui, VC., Zhidkova, NI., Tiller, GE., Goldring, MB., et al. (1995). Autosomal dominant and recessive osteochondrodysplasias associated with the COL11A2 locus. Cell. Vol. 80, No. 3, (February 1995), pp. 431-437, ISSN 0092-8674

von der Mark, K., Kirsch, T., Nerlich, A., Kuss, A., Weseloh, G., Glückert, K., et al. (1992). Type $\mathrm{X}$ collagen synthesis in human osteoarthritic cartilage. Indication of chondrocyte hypertrophy. Arthritis Rheum., Vol. 35, No. 7, (July 1992) pp. 806- 11, ISSN 0004-3591

Vuolteenaho, K., Moilanen, T., Hämäläinen, M., \& Moilanen, E. (2002). Effects of TNFalpha-antagonists on nitric oxide production in human cartilage. Osteoarthritis Cartilage, Vol. 10, No. 4, (April 2002), pp. 327-32, ISSN 1063-4584

Wagener, R., Kobbe, B., \& Paulsson, M. (1997). Primary structure of matrilin-3, a new member of a family of extracellular matrix proteins related to cartilage matrix protein (matrilin-1) and von Willebrand factor. FEBS Lett., Vol. 413, No. 1, (August 1997), pp. 129-134, ISSN 0014-5793

Wagner, K., Pöschl, E., Turnay, J., Baik, J., Pihlajaniemi, T., Frischholz, S., et al. (2000). Coexpression of alpha and beta subunits of prolyl 4-hydroxylase stabilizes the triple helix of recombinant human type X collagen. Biochem J., Vol. 352, No. 3 (December 2000), pp. 907-11, ISSN 0264-6021

Wang, CT., Lin, YT., Chiang, BL., Lin, YH. \& Hou, SM. (2006). High molecular weight hyaluronic acid down-regulates the gene expression of osteoarthritis- associated cytokines and enzymes in fibroblast-like synoviocytes from patients with early osteoarthritis. Osteoarthritis Cartilage. Vol. 14, No 14, (December 2006), pp. 12371247, ISSN 1063-4584

Wehrli, BM., Huang, W., De Crombrugghe, B., Ayala, AG. \& Czerniak, B. (2003) Sox9, a master regulator of chondrogenesis, distinguishes mesenchymal chondrosarcoma from other small blue round cell tumors. Hum. Pathol., Vol. 34, No. 3, (March 2003), pp. 263-269, ISSN 0046-8177

Wesche, H., Korherr, C., Kracht, M., Falk, W., Resch, K., \& Martin, MU. (1997). The interleukin-1 receptor accessory protein (IL-1RAcP) is essential for IL-1-induced activation of interleukin-1 receptor-associated kinase (IRAK) and stress-activated protein kinases (SAP kinases). J. Biol. Chem., Vol. 272, No. 12, (March 1997), pp. 7727-31, ISSN 0021-9258

Williams, FM. \& Spector, TD. (2008). Biomarkers in osteoarthritis. Arthritis Res Ther. Vol. 10, No. 1, (January 2008), pp. 101, ISSN 1478-6362

Wobig, M., Dickhut, A., Maier, R. \& Vetter, G. (1998) Viscosupplementation with hylan G-F 20: a 26-week controlled trial of efficacy and safety in the osteoarthritic knee. Clin Ther. Vol. 20, No. 3, (June 1998), pp. 410-423. ISSN 0149-2918

Wu, J., Rush, TS 3rd., Hotchandani, R., Du, X., Geck, M., Collins, E., et al. (2005) Identification of potent and selective MMP-13 inhibitors. Bioorg. Med. Chem. Lett., Vol. 15, No. 18, (September 2005), pp. 4105-4109, 0960-894X

Wu, JJ., Woods, PE. \& Eyre, DR. (1992). Identification of cross-linking sites in bovine cartilage type IX collagen reveals an antiparallel type II-type IX molecular 
relationship and type IX to type IX bonding. J Biol Chem., Vol. 267, No. 32, (November 1992), pp. 23007-14, ISSN 0021-9258

Wu, JJ. \& Eyre, DR. (1998) Matrilin-3 forms disulfide-linked oligomers with matrilin-1 in bovine epiphyseal cartilage. J. of Biol. Chem. Vol. 273, No. 28, (July 1998), pp. 1743317438 ISSN 0021-9258

Xie, D. \& Homandberg, GA. (1993). Fibronectin fragments bind to and penetrate cartilage tissue resulting in proteinase expression and cartilage damage. Biochim Biophys Acta. Vol. 1182, No. 2, (September 1993), pp. 189-196, ISSN 0006-3002

Zhu, Y., Wu, JJ., Weis, MA., Mirza, SK. \& Eyre, DR. (2011). Type IX Collagen NeoDeposition in Degenerative Discs of Surgical Patients Whether Genotyped Plus or Minus for COL9 Risk Alleles. Spine (Phila Pa 1976)., Epub ahead of print. (February 2011), ISSN 1528-1159 


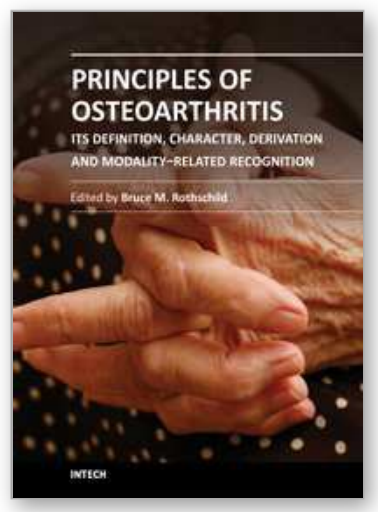

\section{Principles of Osteoarthritis- Its Definition, Character, Derivation and Modality-Related Recognition}

Edited by Dr. Bruce M. Rothschild

ISBN 978-953-51-0063-8

Hard cover, 590 pages

Publisher InTech

Published online 22, February, 2012

Published in print edition February, 2012

This volume addresses the nature of the most common form of arthritis in humans. If osteoarthritis is inevitable (only premature death prevents all of us from being afflicted), it seems essential to facilitate its recognition, prevention, options, and indications for treatment. Progress in understanding this disease has occurred with recognition that it is not simply a degenerative joint disease. Causative factors, such as joint malalignment, ligamentous abnormalities, overuse, and biomechanical and metabolic factors have been recognized as amenable to intervention; genetic factors, less so; with metabolic diseases, intermediate. Its diagnosis is based on recognition of overgrowth of bone at joint margins. This contrasts with overgrowth of bone at vertebral margins, which is not a symptomatic phenomenon and has been renamed spondylosis deformans.

Osteoarthritis describes an abnormality of joints, but the severity does not necessarily produce pain. The patient and his/her symptoms need to be treated, not the x-ray.

\section{How to reference}

In order to correctly reference this scholarly work, feel free to copy and paste the following:

Chathuraka T. Jayasuriya and Qian Chen (2012). Cartilage Extracellular Matrix Integrity and OA, Principles of Osteoarthritis- Its Definition, Character, Derivation and Modality-Related Recognition, Dr. Bruce M. Rothschild (Ed.), ISBN: 978-953-51-0063-8, InTech, Available from: http://www.intechopen.com/books/principles-ofosteoarthritis-its-definition-character-derivation-and-modality-related-recognition/cartilage-extracellular-matrixintegrity-and-oa

\section{INTECH}

open science | open minds

\section{InTech Europe}

University Campus STeP Ri

Slavka Krautzeka 83/A

51000 Rijeka, Croatia

Phone: +385 (51) 770447

Fax: +385 (51) 686166

www.intechopen.com

\section{InTech China}

Unit 405, Office Block, Hotel Equatorial Shanghai

No.65, Yan An Road (West), Shanghai, 200040, China

中国上海市延安西路65号上海国际贵都大饭店办公楼 405 单元

Phone: +86-21-62489820

Fax: $+86-21-62489821$ 
(C) 2012 The Author(s). Licensee IntechOpen. This is an open access article distributed under the terms of the Creative Commons Attribution 3.0 License, which permits unrestricted use, distribution, and reproduction in any medium, provided the original work is properly cited. 